Investigation of the institutional and decision-usefulness factors in the implementation of accrual accounting reforms in the public sector of Tanzania

\begin{tabular}{|r|l|}
\hline Journal: & Journal of Accounting in Emerging Economies \\
\hline Manuscript ID & JAEE-01-2018-0005.R5 \\
\hline Manuscript Type: & Research Paper \\
\hline Keywords: & Accrual accounting, Central government, Tanzania, Institutional theory \\
\hline
\end{tabular}




\title{
Investigation of the institutional and decision-usefulness factors in the implementation of accrual accounting reforms in the public sector of Tanzania
}

\begin{abstract}
Purpose: The paper investigates the factors which have resulted in the effective implementation of accrual accounting reforms in the central government of Tanzania.

Design/methodology/approach: The paper relies on the ideas of institutional theory and some aspects of decision-usefulness so as to delineate the external pressures enforcing the government of Tanzania to embrace accrual accounting and the factors complicating its implementation at organisational level (within government entities). We draw on quantitative techniques and the explanatory and cross-sectional survey research strategies and methods for data analysis.
\end{abstract}

Findings: Our findings suggest that the coercive pressures from donors and auditors along with the normative pressures surfaced by the training of employees generate a significant impact on designing the effective administrative model of accrual accounting. In a lesser extent, pressures from the National Board of Accountants and Auditors and cultural factors are positively correlated to the implementation of accrual accounting in the Tanzanian context. Of the factors we examined, the management changes are proved to be least effective. Unawareness of the key stakeholders has caused weak political and regulatory commitments. Accrual accounting implementation is further exacerbated by inadequate technical and personnel competence. Ultimately, the implementation of the accrual accounting has increased significant managerial accountability though a major segment of such behavior is unexplained by the factors we employed in the study.

Practical implications: The effective implementation of accrual accounting relies on improvements in cultural and human-related issues. What is important to understand is that accrual accounting is more of a management reform incorporating changes in broader aspects of institutional and accountability mechanisms, rather than just an adoption of particular accounting technologies. Without such broader changes, accrual accounting reforms can be detrimental providing the technocrats and government officials with a space for manipulating financial information, Tanzania serving as an example.

Originality/value: The study highlights the case of an emerging economy in which accrual accounting is actually in effect and has impacted on managerial accountability, but is struggling to engender intended results and outcomes at organisational level.

Key words: Accrual accounting, Central government, Tanzania, Institutional theory 


\section{Introduction}

The paper aims at investigating the implementation of accrual basis of accounting in the central government of an emerging economy: Tanzania. Public sector accounting reforms, mainly the widespread adoption of accrual accounting across western governments, have continually drawn attention of researchers (Steccolini, 2019; Bruno and Lapsley, 2018; Hyndman and Liguori, 2018; Christensen et al., 2018). International organisations and standard setters (e.g. the World Bank and the International Federation of Accountants), professional accountants and their firms (e.g. EY and PwC), and regional policy makers (e.g. the European Commission) advocate the importance of accrual accounting for improving transparency in resource allocation, identifying full costs of government activities and ensuring sustainability of governments' fiscal policies (Adhikari and Gårseth-Nesbakk, 2016). More detailed benefits of accrual accounting, both at the institutional and organisational levels, are outlined in the reports published by these organisations (Athukorala and Reid, 2003; Cavanagh et al., 2016; FEE, 2007; IFAC, 2011). The push for accrual accounting has been further reinvigorated in the aftermath of the sovereign debt crisis, predicating it a panacea through which to prevent such financial catastrophes in the future (Ball, 2012; Ball and Pflugrath, 2012).

However, debates on the need and significance of accrual accounting in the public sector have also persisted at academic level. While some scholars have envisaged it as an intervention of neo-liberalism at the expense of public services and welfare (Ellwood and Newberry, 2007), others tend to delineate unintended consequences led to by its technical ambiguities and implementation costs (Hyndman and Liguori, 2018; Oulasvirta, 2014). The experience of implementing accrual accounting even in the context of Anglo-Saxon countries, which are claimed to be at the forefront of public sector accrual reforms, shows that costs have outweighed the benefits of accruals and that the sophisticated accounting information, as generated through the use of accrual accounting, has rarely been applied in the budgeting process and financial decision-making (Adhikari and Gårseth-Nesbakk, 2016; Ezamel et al., 2014; Guthrie, 1998; Wall and Connolly, 2016). However, such lessons have hardly been reckoned by international organisations, as they keep on executing pressures to emerging economies for a transition towards accrual accounting, reiterating ideological jargon such as good governance and economic advancement (Goddard, 2010; Hopper et al., 2017; Hopper, 2017). Emerging economies have also been offered an alternative pathway, enabling them to pursue an incremental approach towards accrual accounting, first, by fully complying with the 
requirements laid down in the Cash Basis IPSAS. This approach, which is particularly evident in South Asia (Salah et al., 2018; Adhikari et al., 2015; Adhikari and Mellemvik, 2010) and Africa, has, however, turned out to be a complete failure in that more than 31 African governments had to abandon the IPSAS project as the requirements, mainly the preparation of consolidated accounts, proved impractical (Wynne, 2012 and 2013; IPSASB, 2017). Failure, resistance and unintended consequences, including delay and chaos, have become a central feature of internationally-propagated public sector accounting reforms in emerging economies (Hopper et al., 2017; Soobaroyen et al., 2017; Van Helden and Uddin, 2016). Recent studies have emphasised the need for adopting incremental, indigenous and participatory approaches to public sector accounting reforms in emerging economies, rather than promoting particular accounting technologies (see e.g. Lassou et al., 2018; Salah et al., 2018), accrual accounting and IPSASs serving as examples, the significance of which are continually questioned in western countries (Christensen et al., 2018; Oulasvirta, 2014; Hyndman and Connolly, 2011), let alone emerging economies.

Our research setting, the Tanzanian central government, appears to be rather distinct, as compared with many other emerging economies involved in public sector accounting reforms, in a number of aspects. Firstly, limited studies are available in emerging economy contexts focusing particularly on the implementation of accrual accounting (Adhikari and Mellemvik, 2011; Harun et al., 2012). Studies undertaken in Asia (Adhikari et al., 2013; Salah et al., 2018), Africa (Lassou, 2017; Lassou and Hopper, 2017; Lassou et al., 2018) and Latin America (Brusca et al., 2016) tend to cover a variety of New Public Management (NPM) reforms ranging from medium-term expenditure frameworks to performance reporting to the adoption of the Cash Basis International Public Sector Accounting Standards. Tanzania has a long history of public sector accounting reforms, which started at the behest of international organisations, mainly the World Bank, at the beginning the 1990s (Goddard and Mkasiwa, 2016; Goddard and Mzenzi, 2013; Goddard et al., 2016). Since 2012 all central level agencies have been preparing their financial statements following accrual principles (URT, 2013a and 2013b). The significance of accrual accounting has been predicated in Tanzania on the assumption that it would strengthen the government's accountability in managing and allocating public resources (URT, 2014). Tanzania perhaps represents a rare research setting in emerging economy contexts in which accrual accounting is actually in effect. 
Next, extant work on public sector accounting reforms in emerging economies delineates the negative impact of the implementation of NPM accounting reforms and resistance to changes (Adhikari and Jayasinghe, 2017; Busca et al., 2016; Harun et al., 2012). On the contrary, public sector reforms in Tanzania, including accounting reforms, reflect more of, according to Goddard and Mkasiwa (2016, p. 342), a 'struggle for conformance' to the reform requirements rather than their resistance (see also Goddard et al., 2016). This is even more evident in the implementation of accrual accounting as it has proved inadequate in terms of generating relevant information about assets, liabilities, revenues and expenditures (e.g. see the CAG reports of 2013/2014, 2014/2015 and 2015/2016). The CAG reports demonstrate the fact that the propagated benefits of accrual accounting have rarely been realised in practice due to its poor implementation (URT, 2013a, 2014 and 2015). Commitments are, however, made at institutional level to improve accrual accounting practice. In this regard, Tanzania offers a unique research setting to explore the implementation phase of accrual accounting in emerging economies.

It is argued that contextual and other institutional factors, including culture, technology, politics, administration and nepotism, to name just a few, significantly affect public sector accounting practices in emerging economies. However, relatively little is known about the impact of these factors in implementing accrual accounting, a research gap which this study intends to address. Drawing primarily on institutional theory (Meyer and Rowan, 1977; DiMaggio and Powell, 1983) and some aspects of decision-usefulness, our aim in this paper is to investigate the key factors influencing the implementation of accrual accounting in the central government of Tanzania. While the use of institutional theory has helped us identify the institutional pressures enforcing the government of Tanzania to embrace accrual accounting, the ideas of decision-usefulness have enabled us to shed light on the factors influencing the effective implementation of accrual accounting at the organisational level (within government entities). The usefulness of institutional theory in exploring the choice of accounting practices in the public sector of emerging economies is evident in prior work (Adhikari et al., 2013; Harun et al., 2012; Salah et al., 2018). Coupling with the ideas of the decision-usefulness concept, we have extended the scope of institutional theory delineating the factors that institutionally-propagated ideas, accrual accounting in our case, can faced in the implementing phase. 
The remainder of the paper is structured as follows. The next section discusses prior work on public sector accounting in emerging economies in general, and Africa in particular, and outlines the research gap in this field. We then present institutional theory, which we have drawn to frame our work. Following the research method in section four, we present our data analysis illustrating how different factors have been effecting the implementation of accrual accounting in the central government of Tanzania. Lastly, the final section analyses our findings through the theoretical lenses applied and offer some concluding comments.

\section{Public sector accounting reforms in emerging economies with a focus on Africa}

Studies on public sector accounting in emerging economies have expanded in the last two decades. Initially, such studies were focused on investigating the role that international organisations, mainly the World Bank and the International Monetary Fund (IMF), had played in promoting key neo-liberal ideas, such as privatisation and disseminating various New Public Financial Management (NPFM) measures (Guthrie et al., 1999) at different levels; performance reporting; programme budgeting, underpinned by the medium-term expenditure framework; commitment accounting; and integrated financial management systems (IFMIS) (Nyamori et al., 2017; Uddin and Hopper, 2001 and 2003). Despite being an important loan conditionality and an integral component of structural adjustment programmes, all such neo-liberal ideas and NPFM measures imposed on emerging economies had minimal impact in practice in terms of improving governance and accountability, and stimulating economic growth (Hopper et al., 2009; Alawattage et al., 2007; Uddin and Hopper, 2001 and 2003; Uddin and Tsamenyi, 2005; Neu et al., 2009). Critics against international organisations for their coercive intervention in the public sector of emerging economies have steadily augmented over time (Josiah et al., 2010). More recently, these organisations are urged to promote incremental changes while disseminating NPFM reforms, taking into account the local contexts of emerging economies (Hopper et al., 2017; Van Helden and Uddin, 2016; Soobaroyen et al., 2017).

Accounting, which was continually conceived of as being a technical matter, drew relatively little attention until the notion of good governance was brought forth on top of the reform agenda of international organisations at the beginning of the new century (World Bank, 2008; Nyamori et al., 2017; Hopper, 2017). The adoption of accrual accounting was then envisaged as indispensable to ensure good governance by promoting transparency and accountability in public resources management and eradicating corruption. Similar to other NPFM measures, 
extant work demonstrates that attempts to implement accrual accounting have remained futile in emerging economy contexts. Several factors, including implementation costs, a lack of trained accountants and professionals, poor accounting infrastructure, mainly inadequate IT, rigid organisational structures and limited demand of accounting information, all tend to result in a failure to implement accrual accounting in emerging economies. For instance, in their study of accrual accounting in the public sector of Nepal, Adhikari and Mellemvik (2011) demonstrate how a lack of human resources, inadequate accounting infrastructure and poor communication at internal level forced the country to abandon accrual accounting and revert to cash accounting and the Cash Basis IPSAS. Such is also evident in Bangladesh (Salah et al., 2018) and Sri Lanka (Adhikari et al., 2013) where a lack of professional engagement not only delayed the implementation process of accrual accounting but also questioned its applicability at central government level. In a similar vein, studies conducted in Indonesia have delineated the fact that despite the adoption of accrual accounting at different administrative levels, the prevalence of the historically institutionalised control-oriented public administration, inadequate accounting skills amongst public accountants and a poor designing of reforms have seriously hindered its widespread application, thereby keeping the old-styled cash accounting intact in practice (Harun et al., 2012, 2015; McLeod and Harun, 2014). Studies conducted in Latin America show that countries in the region have put more emphasis on convergence with accrual basis IPSASs, but their efforts have been thwarted by the technicalities inherited into these standards (Busca et al., 2016; Manes-Rossi et al., 2016).

Public sector accounting reforms in Africa have apparently drawn more critics than reforms undertaken in any other emerging economy contexts (Hopper et al., 2017; Hepworth, 2015; Nyamori et al., 2017). In the case of Africa, international organisations have been alleged to contribute to the dismantling of the entire public finance system propagating western reforms, and any discernible achievements of such changes in actual practice are virtually non-existent (Lassou, 2017; Hopper, 2017). For instance, in their studies of government accounting reforms in Benin, Ghana and a country in Francophone Africa, Lassou and Hopper (2016) and Lassou (2017) have illustrated how such reforms have further exacerbated the existing practices and proved problematic. Hopper et al. (2017) state that international organisations still consider public sector accounting reforms merely technical and hold the assumptions that accrual accounting and IPSASs are equally suited in the African contexts as in other developed country contexts; the success of accrual accounting in developed country contexts are also claimed to be untested (Christensen et al., 2018; Bruno and Lapsley, 2018). The fact that the successful 
implementation of accrual accounting is connected to cultural and management changes (Hepworth, 2015) has been ignored and also that the success factors for any reforms, not least accrual accounting, including the consideration of local contexts, participatory approaches and incremental changes are largely negated in the reform process. As such, the coercive dissemination of accrual accounting and IPSASs has resulted in disastrous results in Africa creating a space for corruption, patronage politics and neo-patrimonialisms to proliferate (Salah et al., 2018; Nyamori et al., 2017). For instance, in their study of IPSAS reforms in the Nigerian central government, Bakre et al. (2017) have illustrated how government officials manipulated the implementation of IPSAS 17, which enabled them to continue applying the historical cost accounting in property valuation rather than fair value, as required by the standard, and become involved in corruption. Lassou (2017) states that the adoption of IPSASs in Ghana further weakened the formal accountability mechanisms and opened up the space for corruption, as it was circumvented by the existing informal institutions, patronage and clientelism. In a similar vein, Goddard et al. (2016) illustrate how the adoption of IPSASs in Tanzanian local government councils has instigated malpractices, as the councils stamped all their financial statements as fully IPSAS-compliant so as to convince the supervisory bodies and funders. The role that IPSASs have played in promoting bad practices with a view to ensuring legitimacy is also evident in South Africa (Van Wyk, 2007).

Despite such critics, a number of countries in Africa, including Nigeria, Tanzania and South Africa, have continued their public sector accounting reform efforts, replacing the existing cash accounting with accrual accounting and accrual IPSASs (Bakre et al., 2017; Goddard et al., 2016; Van Wyk, 2007). As such, calls have been made to expand our understanding of local contexts and factors, which tend to influence the implementation of accrual accounting in emerging economies (Harun et al., 2012 and 2015; Soobaroyen et al., 2017). It is this research gap that this paper intends to address. Our objective in this paper is not to engage in a discussion as to whether and to what extent accrual accounting and IPSASs are relevant to Africa. Instead, we investigate a case in which accrual accounting is already in effect and bring out the factors influencing the effective implementation of accrual accounting in an emerging economy, presenting the case of the central government of Tanzania. Unlike many other emerging economy countries in which accrual accounting has been resisted at different administrative levels (Adhikari and Jayasinghe, 2017; Salah et al., 2018), Tanzania appears to be determined to conform to accrual accounting reforms, but is 'struggling for conformance' (Goddard and Mkasiwa, 2016; Goddard et al., 2016). We add to extant work in public sector accounting in 
emerging economies, delineating how a local context influences accrual accounting and identifying factors which result in variations in this accounting implementation across countries.

\section{Theoretical framework}

Institutional theory and its relevance to legitimising accrual accounting

The dissemination of accrual accounting in the public sector is often associated with institutional theory (Jacobs, 2012; Modell, 2009, 2013). The theory has enabled accounting researchers to explain many important issues relating to public sector accounting reforms; for instance, the engagement of international organisations and development partners, the diffusion of similar ideas and outcome variation, amongst others (Ahn et al., 2014; Carpenter and Feroz, 2001; Hyndman and Connolly,2011; Oulasvirta, 2014; Pollanen and Loiselle-Lapointe, 2012; Carruthers, 1995). In general, institutional theory explores the relationship between individuals, society and state within the organisational practice and reveals the aspects inconsistent with an 'organisation's formal accounts' (DiMaggio, 1991). Organisations are envisaged as rational actors with limited choices, and the social, cultural, political and institutional factors provide a means through which to legitimise and support organisational activities (DiMaggio and Powell, 1983; Meyer and Rowan, 1977). Meyer and Scott (mentioned in Scott, 1991) define legitimacy as a cultural support mechanism, the extent of which explains the existence of any practice. However, there should be a limit on legitimacy-seeking behaviours given that the sovereignty of different organisations over any individual organisation adversely affects the scope of legitimacy and turns organisations into battlefields of their governing bodies in a particular context. Accounting as an organisational practice is embedded in the social and institutional context in which it operates (Hopwood, 2000), and by using institutional theory, it is therefore possible to identify factors influencing and legitimising the implementation of accrual accounting in the public sector of Tanzania.

Using organisation as a unit of analysis, institutional theory unveils diffusion at local level (DiMaggio, 1991, p. 286), why particular types of economic behaviour emerge among the organisation's actors and also how the same root of internal organisational institutions influences actors to behave in a particular way (Scapens, 2006; Mbelwa, 2015). From the analytical aspects, institutional theory can be analysed from three logical perspectives: 
coercive, memetic and normative. The first perspective, also referred to as 'coercive isomorphism', is a result of formal and informal pressures exerted on organisations by other organisations, upon which they depend for financial resources and/or cultural expectations from the society the organisation is embedded in (DiMaggio and Powell, 1983). Coercive isomorphism creates new organisational practice, which is rationalised in reference to the homogeneity and ritual conformity with other institutions. One of the mechanisms of coercive isomorphism is a regulatory change by the dominating institution that often requires follower organisations to transform their form and structure. By studying Portuguese public accounting reform, Jorge et al. (2007) argue that the implementation of accrual accounting has changed local standards and institutionalised the new accounting practice.

The second logical perspective of institutional theory is the normative isomorphism that refers to relations between management policies and the background of employees in terms of educational level, job experience and networks of professional associations (Najeeb, 2014). It is associated with professionalisation, which is often interpreted as the collective struggle of members of an occupation to define conditions and methods of their work, to control the production by producers and to establish a cognitive base and legitimacy for their occupational autonomy (DiMaggio and Powell, 1983). Establishing a normative isomorphism by employing personnel sharing similar professional associations and institutions (e.g. university, trade union, etc.) enables an organisation to anticipate professional handling of organisational issues because professionals sharing the same institutional and educational background might possess similar professional and personal skills, expectations and standard approach to produce and reproduce their day- to- day organisational practices (ibid). Since accrual accounting requires a standardised process of record-keeping and reporting as well as the distribution of the report to users, the knowledge, experiences, presentation, professional background and affiliations of personnel play a paramount role in institutionalised the accounting practice.. Using institutional theory, Rollins and Bremser (1997) find that the big audit firms seek social legitimacy and public confidence through their well-documented policies and procedures that also demonstrate institutional conformity with the framework commissioned by corporate watchdogs, like the Securities and Stock Exchange Commission.

The third perspective, i.e. the mimetic isomorphism, is operationalised in response to uncertainties - a rather voluntary process initiated by the organisation itself than the coercive isomorphism. According to DiMaggio and Powell (1983), symbolic uncertainty of 
environment, inadequate technological know-how and ambiguous short- and long-term strategies may encourage an organisation to mimic other organisations that appear to be more successful. As DiMaggio (1991) argues, although organisations might be visibly different, any organisation's adherence to another organisation's 'form per se' in respect of structures, missions and programmes increase legitimacy and efficiency; for instance, an attachment to western culture is often rationalised as a question of 'efficiency' and 'democracy'. An organisation may knowingly or unknowingly mimic other organisations by modelling their activities, structures or functions on the leading organisation, the success of which often rests on how human resources of the follower organisations are managed (DiMaggio and Powell, 1983). The pressures of serving a wider base of customers, shareholders, employees and other stakeholders encourage mimetic isomorphism in which the follower organisations seek legitimacy by structural adjustments drawn closer to the lead organisation, though the efficiency in such mimetic isomorphism is questionable (DiMaggio, 1991; Oliver, 1991).

In respect of power and politics in institutionalising a particular practice, professionals are more inclined to bring those changes at intra-organisational level, which enables them to apply better control over organisational resources (DiMaggio, 1991). Administrative professionals legitimise their power and influence by articulating their commitments both to professional bodies and employing organisations in bringing up changes from cash accounting to accrual accounting initiated by professional bodies and partly due to the pressure from the professional bodies on their members to mimic the practices at the organisational level (Carpenter and Feroz, 2001). However, in revelations of discrepancies with formal practices, these professionals may clash with the very organisations that have employed them and have delegated necessary authorities and responsibilities by weaponising their education, training and ethos acquired from the professional institution, thus providing a means for domination in an uncertain context (DiMaggio, 1991). It is especially appalling for non-profit organisations in which due to the absence of profit mechanisms, the legitimacy relies more on professional ethics, experiences and disinterest of pecuniary gains, and experiences count more in establishing legitimacy; the institutional sources of legitimacy dominate over the technical ones (DiMaggio, 1991).

Due to the nature of public organisation, the implementation of accrual accounting in an organisation requires political will, management support and management change. Political will means a strong desire or determination on the part of the government or state to make 
something happen. The level of political commitment is crucial to the effective implementation of accrual accounting in public sector financial reporting, since changing the basis of accounting requires considerable financial and non-financial resources along with long-term commitment. It is also necessary to legitimise the role of the public sector working as a pressure group to other institutions dependent on it for resources (Martin and Jérôme, 2016). Studying reforms in government accounting in New Zealand and the UK, Ellwood and Newberry (2007) find that the institutionalisation of accrual accounting in the public sector reduces the debate of the government's dual role as 'procurer of services' and 'rule setter' that nurtured a culture of transparency and accountable society. It is therefore important to continue to liaise with key politicians throughout the process of implementing accrual accounting (IFAC, 2011). Kotter (2011) argues that political and managerial actors should be committed and willing to change the underlying standards of financial reporting in order to make better economic decisions, and improve accountability and transparency of public funds. Thus, institutional theory explains the successful/failed attempt to institutionalise an organisation's practices by examining organisational preparedness, flexibility, allocated resources and extent of resistance (Timoshenko and Adhikari, 2009; Adhikari and Mellemvik, 2011; Ellwood and Newberry, 2007; Gibassier, 2017; Hyndman and Connolly, 2011).

Our theoretical framework also proposes to accommodate pressures from various institutions, which are associated with coercive, normative and mimetic mechanisms (DiMaggio and Powell, 1983; Collier, 2001; Kurunmaki et al., 2003; Mbelwa, 2015; Goddard and Mzenzi, 2013; Adhikari and Gårseth-Nesbakk, 2016). The move from cash to accrual accounting in public sector financial reporting may have resulted from the pressures (coercive, normative or mimetic) from various international institutions, such as the International Monetary Fund and the World Bank (Adhikari and Mellemvik, 2011; Adhikari et al., 2013; Churchill, 1992). These institutions issue rules and regulations for particular countries, including Tanzania, to comply with in order to get crucial financial assistance. Furthermore, these international organisations worked jointly with international accountancy professional bodies, such as the International Federation of Accountants (IFAC), so as to facilitate changes in the system of government accounting in emerging economies (Churchill, 1992; Salah et al., 2018; IFAC, 2011).

\section{Effective implementation of accrual accounting}


The implementation of accrual accounting can be categorised as administrative implementation, symbolic implementation, experimental implementation and political implementation (Arnaboldi and Lapsley, 2009). Administrative implementation of accrual accounting involves the situations where, with both low conflict and ambiguity, the process of implementation is primarily managerial. On the other hand, the experimental model is where there is little opposition to a new policy but there are ambiguous goals and means, and key actors can experiment with the implementation of accrual accounting (Arnaboldi and Lapsley, 2009). Moreover, the symbolic model of implementation of accrual basis accounting is nonimplementation of policy, which means that conflict and disagreements tend to be resolved by coercion (Arnaboldi and Lapsley, 2009). The last one is a political model of implementation in which conflict and resistance reside at the macro level and where policy options, goals and objectives are clear (Arnaboldi and Lapsley, 2009). This study describes the effective implementation of accrual accounting in the administrative model of implementation.

Effectiveness means the degree to which objectives are achieved and problems resolved. In the accounting field, effectiveness implies the extent to which financial reports are relevant, reliable, understandable and transparent (Mbelwa, 2015; Chalu, 2007). This asserts that the effective implementation of accrual accounting can be measured by the extent to which qualitative characteristics of financial statements, such as relevance, reliability, understandability and transparency, are achieved. The qualitative characteristics are explained by the decision-usefulness concept, which states that financial statements are effective if they provide information to interested parties to facilitate decision-making processes and demonstrate accountability (Staubus, 1960; Schipper and Vincent, 2003). Thus, for the financial statement to be useful and effective in discharging accountability, it should be relevant (Staubus, 1960; Schipper and Vincent, 2003; Sutton, 2009). Relevance and reliability are primary qualities that explain financial statements' usefulness in discharging accountability (Staubus, 1960; Bruns, 1968; Williams, 1987; Jones, 1992; Coy et al., 2001; Schipper and Vincent, 2003; Sutton, 2009; Mbelwa, 2015). If one of them is completely missing from a piece of information in financial statements, the information will not be useful and effective in discharging accountability (Bruns, 1968; Mbelwa, 2015). Relevance is the capacity of information to make a difference in decision-making and in discharging accountability (Bruns, 1968; Mbelwa, 2015). According to Sutton (2009), relevance is synonymous to decision usefulness and is combined with stewardship as an obligation of providing information on resources one is entrusted with. 
This information has to allow for the provision of feedback value, as well as predicting the results of events occurring in the past, present and future (Beaver et al., 1998). Reliability is an essential characteristic for accounting information's usefulness in decision-making. It is the quality of information that permits users to depend on it with confidence (Mbelwa, 2015). Moreover, reliability represents the extent to which the information is unbiased and free from error (Mbelwa, 2015). A significant change of primary qualitative characteristics has occurred: reliability has changed to representational faithfulness, with the change beginning in the late 1980s (Sutton, 2009). Reliability, as representational faithfulness, includes elements such as verifiability, neutrality and completeness (Sutton, 2009). The quality of accounting information in terms of reliability and variability plays a significant role in information use and it is essential in satisfying users (Mbelwa, 2015).

Decision usefulness, as an objective of accounting information use, needs users to understand the information (Staubus, 1960; Beaver et al., 1998; Sutton, 2009). Understandability is a userspecific quality, as users differ in their ability to comprehend any set of information due to differences in cognitive ability, knowledge, experience and expertise (Al-Maskari and Sanderson, 2011). Understandability increases when the information is classified and characterised, and presented clearly and concisely (Beest et al., 2009).At the preparation stage, the reporting entity is required to devise a reporting format that meets the need for comparability or relevance. Dillon et al. (2010) posit that there are commonly accepted accounting information characteristics: timeliness, completeness, reliability, consistency, relevance, objectivity and understandability. Generally, the study operationalises the effective implementation of accrual accounting by looking at an organisation's financial statements and ensuring that such characteristics are present. The literature posits that the implementation of accrual accounting conveys information with relevant qualities, and demonstrates accountability not feasible under cash accounting (Lapsley et al., 2009).

\section{Institutional theory}

Accountability means the obligation of an individual or organisation to account for its activities, accept responsibility for them and disclose the results in a transparent manner. It may also include the responsibility for money or other entrusted properties. There are different types of accountabilities such as managerial accountability, financial accountability and political accountability (Chi-chi and Ebimobowei, 2012).The institutional theory posits that any 
organisation may build their own accountability structure, often following the system and/or process of other institutions. The organisation may have their own logics and interpretations of the accountability practice in place (Vamosi, 2005). Vamosi (2005) acknowledges a degree of voluntarism in determining the extent of accountability by organisational actors or a particular unit of organisation. Owing to their psychological set-up (e.g. beliefs, attitudes, moral, ethics etc.), organisational actors may passively determine their degree of autonomy, actions and ultimately a level of accountability. The broad, complex and often indeterminate structure of assessing and evaluating public benefits make the accountability mechanism in the public sector much more complicated as compared with the private sector in which shareholdermanager relationship is precisely determined and the extent of accountability is systematically negotiated (Samkin and Schneider, 2010). Again, the wholesale adaption of private organisation for public institutions, some of which are characterised by non-profit, cultural and heritage custody of public assets may backfire the intended benefits of reforms as observed in accounting reforms in the Australian public sector (Potter, 2002).

Therefore, the nature of public organisations, pressures from the state for necessary information (Gomes et al., 2008) and the institutional isomorphism in determining a level of accountability for public organisations need to be carefully examined in evaluating its effectiveness. In accounting literature, the institutional theory examines financial and managerial accountability (Potter, 2002; Samkin and Schneider, 2010; Vamosi, 2005; World Bank, 2008). Financial accountability means holding individuals accountable for performing a financial procedure effectively within a financial transaction process. A well-defined financial accountability structure serves as the effective financial process (World Bank, 2008). Managerial accountability is the obligation of unit managers to perform all activities observing the principles of sound financial management, legality and transparency in administration, and taking responsibilities for their actions and results. Managerial accountability also covers responsibility for the actions committed (World Bank, 2008). World Bank's study operationalises accountability as financial, political and managerial accountability that is measured by the extent to which the management/technocrats fulfil their accountability role and that financial statements demonstrate the results of the stewardship of management, or the accountability of management. Mehr (2015) conducted a study on the assessment of the usefulness of accrual accounting on reporting, transparency and accountability of the central government ministry, thereby revealing the fact that accrual accounting has significant influence on the transparency of financial reporting. The data were collected using Likert 
questionnaires and analysed using descriptive and inferential statistics such as the Chi-square test and the student T-test.

Accrual accounting by outlining full-costs of the services provided shrines greater managerial accountability. Bastani et al. (2012) conducted a study to investigate the role of accrual accounting deployment in promoting transparency and accountability in the Mazandaran University of Medical Sciences, as one of the subset units of the Ministry of Health and Medical Education, and a sub-system of the public sector using five Likert questionnaires. The findings of the study show that accrual accounting is effective in reporting transparency, promoting accountability and determining the total cost of services. According to the findings, it seems that accrual accounting implementation is an appropriate approach to enhance social accountability of public managers in the country, increase transparency of financial reports, calculate the cost of service, operationalise budgeting, prioritise activities and programmes and optimise future decisions. Bogt (2008) investigated the actual effects in government organisations due to the introduction of accounting changes in Dutch Local Governments by interviewing 23 politicians and professional managers in 12 municipalities and two provinces. The results of the study indicate that accrual accounting contributed positively to the economic basis of decision-making and the functioning of organisations. For instance, it was possible to prepare output budgets by comparing the unit costs of activities and outputs before and after the implementation of accrual accounting. Later studies also focus on the adoption and implementation of accrual-based accounting in relation of the outputs and outcomes of service provision and the devolution of managerial authority in budget allocations and modes of operation following a set of prudent fiscal management principles (Barton, 2009) though very few studies have examined the extent of managerial accountability. We contribute to the scope of these studies by unfolding how the implementation of accrual accounting contributed to accountability in the public sector of Tanzania; the relationship between accrual accounting and accountability is rarely covered in the context of emerging economies. Our theoretical model, consisting of institutional theory, including the notion of managerial accountability and decision-usefulness, is presented in Figure 1. 


\section{Figure 1: Theoretical Model}

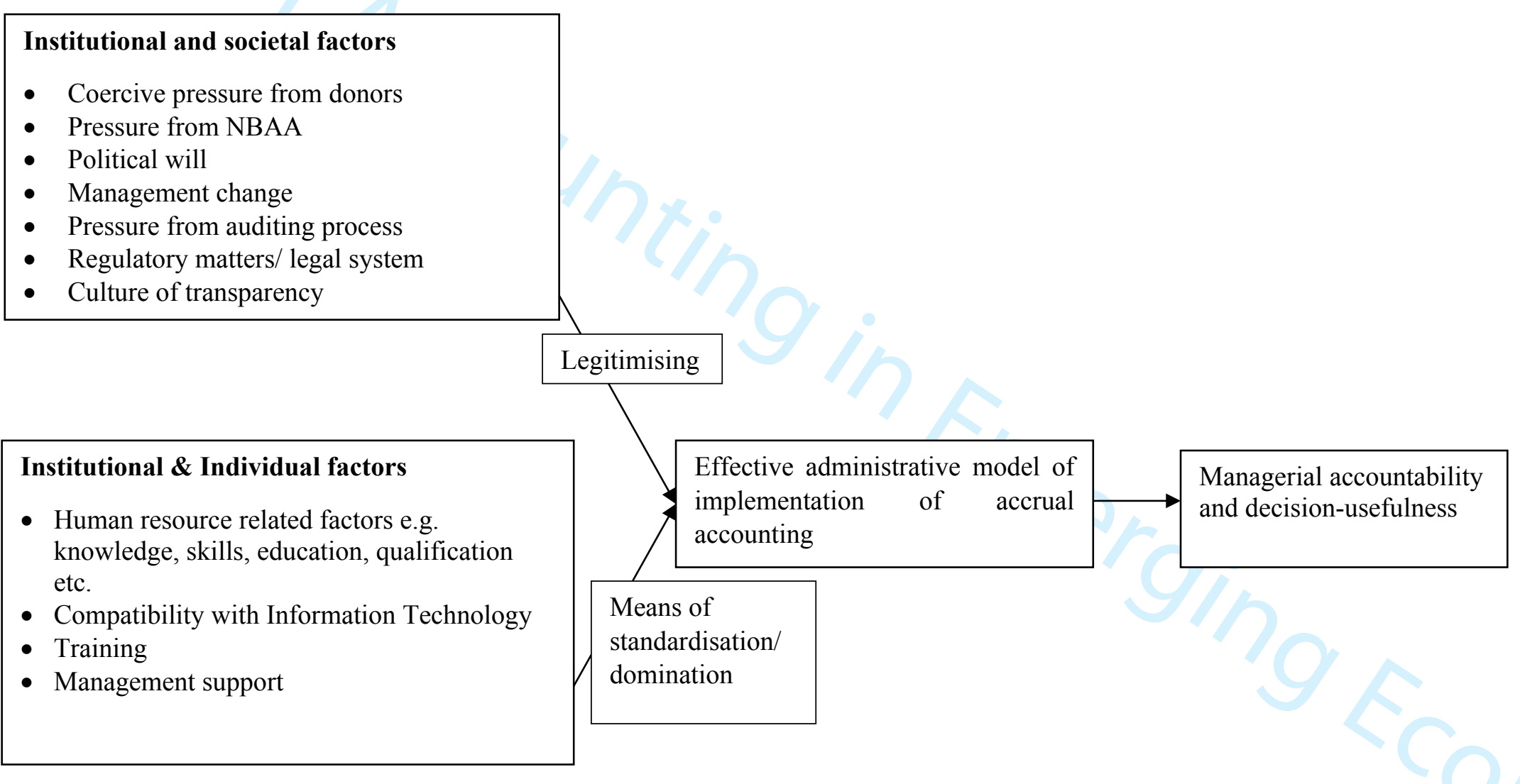


Based on our theoretical model, we propose the following hypotheses

\section{Level 1.}

H1: Institutional and social factors are positively influencing the effective administrative model of implementation of accrual accounting.

H2: Institutional and Individual related factors are positively influencing the effective administrative model of implementation of accrual accounting.

\section{Level 2}

H3: The effective administrative model of implementation of accrual accounting is positively influencing the level of managerial accountability.

\section{Research method}

The study draws on quantitative techniques, and explanatory and cross-sectional survey research strategies and methods have been adopted for data analysis. A crosssectional survey was selected given that it enables researchers to collect data and undertake comparison at a particular point in time. For the purpose of this research, the studied population and the unit of analysis are made up of accountants, auditors and administrators/managers of central government agencies, including the Ministry of Energy and Minerals, the Ministry of Finance and Planning and the Ministry of Work, Transport and Communication. We selected accountants, auditors and managers because of their awareness of accrual accounting and their involvement in adopting and implementing it, and discharging managerial accountability.

Two different rules were adopted in determining the sample size for this study. The first rule underpins the theory of normal distribution, as stated by Baradyana and Ame (2005). They state that the generalisation of the study based on the studied population can be possible as long as the sample size is within a normal distribution, i.e. greater than 30 . The second rule is built on the assumptions of statistical techniques for data analysis. The determination of sample size by considering statistical techniques is emphasised by various scholars (Green, 1991; Baradyana and Ame, 2005). A sample 
size of regression techniques for testing multiple correlations (the direct relationship between independent and dependent variables) and individual predictors is $\mathrm{N}>50+8 \mathrm{~m}$ (whereby $\mathrm{N}$ is a sample size and $\mathrm{m}$ is the number of independent variables) and $N>$ $104+$ m, respectively (Green, 1991; Tabachnick and Fidel, 1996). In this study, we had expected to obtain a sample of 230 respondents from the above-mentioned three ministries. We have used a non-probabilistic sampling technique, particularly judgmental sampling, to ensure that the samples selected are truly representative of the entire population.

Questionnaires were used as a main tool for data collection in the study. This tool enabled us to gather unique information about individuals, such as their attitudes and knowledge in accrual accounting. Taylor-Powell and Hermann (2000), for instance, outline the benefits of using questionnaires to maintain confidentiality and anonymity. We have also applied Exploratory Factor Analysis (EFA) and multiple regression methods for data analysis. The Exploratory Factor Analysis was preferred given its usefulness in data reduction, as well as in ensuring the validity of the study constructs. Multiple regressions were applied to test the relationship between dependent and independent variables of the study.

Particular attention has been paid to ensure the reliability and validity of our data. According to Morgan and Waring (2004), data reliability is a state that exists when data are sufficiently completed, they are error free and are in line with the purpose and context of the study. It asserts that the same data should be collected each time over repeated attempts. We have in this study drawn on Cronbach's alpha to test the reliability of the data used. The Cronbach's alpha reliability coefficient is required to be $>=0.7$, but $>=0.6$ is also generally accepted (Hair et al., 2010). Similarly, validity implies ascertaining that the instrument applied in the study measures what it is intended to measure and that the findings are in line with the expectations (Saunders, 2009). Validity can be of three different forms: internal, external or construct. Internal validity strives to ensure that the study measures what is supposed to be measured (Shenton, 2004). External validity, also known as transferability, concerns with generalisation of the study findings to the larger population (Shenton, 2004). Construct 
validity deals with identifying the right operational measures for the concepts being studied (Yin, 2009). In this study we ensure the validity and reliability of our findings by undertaking Exploratory Factor Analysis. In this analysis, variables in the construct are reduced to obtain critical variables and consistency is maintained while measuring the constructs.

\section{Data analysis \\ Overview of accrual accounting in Tanzania}

Accrual accounting in Tanzania was influenced by the global trends of New Public Financial Management (NPFM) (Guthrie et al., 1999) and was part of the Public Sector Financial Management Reforms (PFMRF) started in 1998 (Goddard and Mkasiwa, 2016; Mkasiwa, 2011). Government agencies started complying with some of the requirements of the Cash Basis IPSAS in 2008 (URT, 2008). In the third phase of the PFMRF, there was a particular focus on ensuring efficiency, effectiveness, transparency and accountability in the use of public resources. As is the case of other developed countries, in particular Australia and New Zealand, accrual accounting was envisaged a means through which to achieve these goals (Harun et al., 2012, 2015). Several potential benefits of adopting accrual accounting have been outlined in the subsequent reports published by the CAG (see e.g. URT, 2008, 2012, 2013a, 2013b). In 2013 government agencies for the first time produced their financial statements adhering to accrual principles and IPSASs. This attempt was heralded in the 2013 report of the Controller and Auditor General stating:

'... I congratulate the Government through the Accountant General for the deliberate effort undertaken to adopt the IPSAS accrual basis of accounting. Apart from the challenging nature, it is beyond doubt that if compared with the cash basis of accounting, accrual basis of accounting provides more comprehensive financial information that is important in guiding managements and other users of financial information in arriving at more informed decisions. While I commend this effort, I also urge the Government, through the Accountant General again, to correctly monitor and 
evaluate implementation of the road map towards the full adoption of the IPSAS accrual basis of accounting'.

However, the experience of the past few years shows that the applicability and implementation of accrual accounting in the central government has not proved sufficient (URT, 2014; Mbelwa, 2015; Goddard and Mzenzi, 2013). A key issue in implementing accrual accounting concerns the preparation of consolidated financial statements, as well as ensuring the reliability of such statements prepared by government agencies. A large number of government agencies have encouraged challenges in identifying their controlled entities; they have applied varied and heterogeneous frameworks for consolidating their accounts and often the transactions have been reported in the consolidated statements without making the adjustments as required by the CAG (URT, 2014). In its report for the financial year 2015/2016, the CAG has mentioned the difficulties that government entities have faced in managing fixed assets, receivables and payables, and reporting their revenues and expenditures, despite the use of innovative payment and collection systems: EFDs. The number of central government entities obtaining qualified and disclaim audit opinions on their financial statements has not been remarkably increased over the last few years (URT, 2015). This clearly signals that the implementation of accrual accounting has not been as effective and efficient as intended despite the generation of information on assets, liabilities, revenue and expenditure. Moreover, the validity and reliability of the accounting information presented by government entities have been questioned. The CAG has in its reports of the financial years 2013/2014, 2014/2015 and 2015/2016 stated that the users have been continually misled due to accrual accounting information (URT 2013a, 2013b, 2014, 2015). This has raised the need for investigating the factors influencing the effective implementation of accrual accounting in central government entities. In this paper we have responded to this call by examining the institutional, contingent and demographic factors influencing the effective implementation of accrual accounting in the central government of Tanzania.

Descriptive analysis 
This section presents the data analysis of the study outlining the factors influencing the effective implementation of accrual accounting in public sector financial reporting of the Tanzanian central government. A set of 230 questionnaires were distributed to the respondents in three different ministries, out of which 204 were duly filled in and returned. This showed a response rate of $88.7 \%$. The population of the study represents those who possess basic knowledge on accounting, including accountant, internal auditors, external auditors and management.

Our findings indicate that a large number of respondents were not aware of when accrual accounting was adopted for the first time in their respective ministries. The results indicate that $38.7 \%$ of the respondents were of the view that accrual accounting was adopted in their respective ministries during the financial year 2012, and the other $17.2 \%$ indicated the financial year 2013. In total, $43.1 \%$ of the respondents were completely unaware of when the accrual accounting system was incorporated in their ministerial financial statements. These results imply that the adoption and implementation of accrual accounting occurred in a phase-wide manner across central government ministries and departments to ensure smooth transformation. The technocrats involved in disseminating accrual accounting across ministries and departments were apparently aware of the transition challenges and therefore facilitated changes in different phases across ministries.

Among our respondents, 52.9\% were accountants, 18.1\% internal auditors, $14.7 \%$ external auditors, $12.7 \%$ represented the management (officers and administrators) and $1.5 \%$ were from other categories. Prior work shows that the implementation of the accrual accounting system is much dependent on the involvement of accountants, auditors and the accounting profession (see e.g. Adhikari et al., 2013; Hopper et al., 2017). Our data indicate that $26 \%$ of the respondents had professional qualifications such as CPA and ACCA. Given the existence of professional qualifications, it can therefore be assumed that the central government had the opportunity to prepare a financial statement complying with the requirements as laid down in accrual IPSASs. The fact that many of our respondents were accountants and auditors also implies that 
there was some level of competency in the central government of Tanzania in applying accrual IPSASs in day-to-day accounting practices. In fact our data analysis indicates that about $81.9 \%$ of the informants were moderately competent and the remaining $18.1 \%$ highly competent in using accrual IPSASs. However, a need for short-term training for existing accountants and auditors was emphasised in order to further increase the level of competency and foster the implementation of accrual accounting.

Operationalisation of constructs/ latent variable, reliability and validity Analysis

Validity provides assurance that the study measures what is supposed to be measured (Shenton, 2004). We have in this study ensured construct validity, identifying appropriate operational measures for the concepts applied (Yin, 2009) and undertaking Exploratory Factor Analysis in which the variables in the construct are reduced to obtain critical variables and maintain consistency in their measurement. In a similar vein, maintaining reliability is paramount to detect errors in coding and ambiguities in instruments. Cronbach's alpha was used to assess the reliability of the scales in which overall reliability coefficients of a construct were determined. The Cronbach's alpha reliability coefficients of the study constructs range from 0.706 to 0.931 (see table 1 below), which are based on an acceptable level (Hair et al., 2010). 
Table1: Operationalisation of Concepts/Constructs

\begin{tabular}{|c|c|c|c|c|}
\hline $\begin{array}{l}\text { Latent } \\
\text { Variable }\end{array}$ & Observable Variable & $\begin{array}{l}\text { Cronbach's } \\
\text { Alpha }\end{array}$ & $\begin{array}{l}\text { Supportive Theoretical } \\
\text { View }\end{array}$ & Empirical Reviews \\
\hline \multirow[t]{6}{*}{$\begin{array}{l}\text { Institutional } \\
\text { Factors }\end{array}$} & $\begin{array}{l}\text { Pressure from donor } \\
\text { 1. Donors put conditions to adapt and implement accrual basis on accessing the } \\
\text { fund } \\
\text { 2. Donors demand quality financial reporting } \\
\text { 3. Financial stress increases the role of donors } \\
\text { 4. Donors restrict access of the fund through financial reporting qualities }\end{array}$ & 0.706 & $\begin{array}{l}\text { Institutional theory-conceive } \\
\text { pressure }\end{array}$ & $\begin{array}{l}\text { Coller (2001); Mbelwa (2015); } \\
\text { Goddard and Mzenzi (2015); } \\
\text { DiMaggio and Powell (1983) }\end{array}$ \\
\hline & $\begin{array}{l}\text { Pressure from NBAA } \\
\text { 5. Professionalism pressure through training and the issuance and adoption of } \\
\text { directives } \\
\text { 6. Pressures from the external standard-setting boards } \\
\text { 7. Professional bodies' interest in communicating latest developments in IPSAS } \\
\text { 8. NBAA report using accrual accounting }\end{array}$ & 0.932 & $\begin{array}{l}\text { Institutional theory-normative, } \\
\text { coercive and mimetic } \\
\text { pressures }\end{array}$ & $\begin{array}{l}\text { Najeeb 2014); DiMaggio and } \\
\text { Powell (1983) }\end{array}$ \\
\hline & $\begin{array}{l}\text { Political will } \\
\text { 1. Political competition on the use of accounting between the users } \\
\text { 2. Pressure parliament audit Committee } \\
\text { 3. Parliament enforcement of the use of accrual basis } \\
\text { 4. Political actors/ ministers enforcing the use of accrual accounting }\end{array}$ & 0.882 & Institutional theory & $\begin{array}{l}\text { Goddard and Mzenzi, (2015); } \\
\text { Mkasiwa (2011) }\end{array}$ \\
\hline & $\begin{array}{ll}\text { Management support } \\
\text { 1. } & \text { Financial support to training } \\
\text { 2. } & \text { Financial support to attend professional conferences } \\
\text { 3. } & \text { ICT equipment in place } \\
\text { 4. } & \text { Recruitment of the professional staff } \\
\text { 5. } & \text { Small the medium size of jurisdictions }\end{array}$ & 0.895 & Institutional theory & $\begin{array}{l}\text { Scapens(2006); } \\
\text { Taipaleenmaki and Ikaheimo, } \\
\text { (2013) }\end{array}$ \\
\hline & $\begin{array}{l}\text { Management changes } \\
\text { 1. Degree of willingness to accept change } \\
\text { 2. Willingness of management to implement accrual basis } \\
\text { 3. }\end{array}$ & 0.844 & & $\begin{array}{l}\text { Ahmad (2016);Arnaboldi and } \\
\text { Lapsley (2009) }\end{array}$ \\
\hline & $\begin{aligned} & \text { Auditing pressure } \\
& \text { 1. } \\
& \text { 2. } \text { Professional compliance influence } \\
& \text { 3. } \text { National audit uses accrual basis accounting/memetic pressure } \\
& \text { 4. } \text { Pressure from internal audit } \\
& \text { 5. } \text { Pressure from the CAG } \\
& \text { 6. } \text { Pressure from audit committees } \\
& \text { 7. } \text { Number of qualified opinions issued } \\
& \text { 8. } \text { Number of unqualified opinions issued }\end{aligned}$ & 0.801 & Institutional theory & $\begin{array}{l}\text { Hay and Cordery } \\
\text { (2018);Goddard and Malagila } \\
\text { (2015); DiMaggio and Powell } \\
\text { (1983); World Bank (2008) }\end{array}$ \\
\hline
\end{tabular}




\begin{tabular}{|c|c|c|c|c|}
\hline & $\begin{array}{l}\text { Regulatory matters/Legal system } \\
\text { 1. Detailed system of statute law has been developed to support and the } \\
\text { harmonised accrual accounting system } \\
\text { 2. Flexible legal system } \\
\text { 3. Harmonised legal system }\end{array}$ & 0.811 & Institutional theory & $\begin{array}{l}\text { Chalu (2007); Mbelwa (2015); } \\
\text { Goddard and Mzenzi, (2015) }\end{array}$ \\
\hline & $\begin{array}{l}\text { Level of technology } \\
\text { 1. Availability of government wide financial reporting information } \\
\text { system/EPICOR } \\
\text { 2. Compatibility of reporting information systems with accrual basis. } \\
\text { 3. Flexible information system }\end{array}$ & 0.722 & Institutional theory & $\begin{array}{l}\text { Cohen et al (2007); Hyndman } \\
\text { and Connolly (2011);Kasim } \\
\text { (2015) }\end{array}$ \\
\hline & $\begin{array}{l}\text { Culture of transparency } \\
\text { 1. Political culture of transparency } \\
\text { 2. Administrative culture of transparency } \\
\text { 3. Harmonisation of accrual accounting culture with working environment } \\
\text { culture }\end{array}$ & 0.781 & Institutional theory & Mbelwa, (2015) \\
\hline & $\begin{array}{cl}\text { Training } & \\
\text { 1. Availability of professional training on accrual accounting } \\
\text { 2. Availability of short-term accounting and audit training } \\
\text { 3. } & \text { Availability of long-term accounting and audit training }\end{array}$ & 0.910 & Institutional theory & $\begin{array}{l}\text { Azmi and Mohamed (2014); } \\
\text { Pina et al. (2009) }\end{array}$ \\
\hline $\begin{array}{l}\text { Human } \\
\text { Resources/Indivi } \\
\text { dual } \\
\text { Actors/Technocr } \\
\text { at-related } \\
\text { Factors }\end{array}$ & $\begin{array}{l}\text { 1. Knowledge, skills, experience and expertise } \\
\text { 2. Proper presentation of FS } \\
\text { 3. Qualification of the personnel/education } \\
\text { 4. General skills in the accounting field }\end{array}$ & 0.868 & Institutional theory & $\begin{array}{l}\text { Pina et al (2009); } \\
\text { Staubus(1960); Schipper, and } \\
\text { Vincent (2003); Sutton (2009); } \\
\text { Beest et al., (2009) }\end{array}$ \\
\hline $\begin{array}{l}\text { Effective } \\
\text { Administrative } \\
\text { Model of } \\
\text { Implementation } \\
\text { of Accrual } \\
\text { Accounting }\end{array}$ & $\begin{array}{l}\text { 1. timeliness, 2. completeness, 3. reliability/faithfulness } 4 \text {. presentation, } 5 . \\
\text { consistency, 6. comparability } 7 . \quad \text { relevance, } 8 . \quad \text { objective and } 9 . \\
\text { understandability }\end{array}$ & 0.931 & sefulness Concept & $\begin{array}{l}\text { Staubus (1960); Schipper, and } \\
\text { Vincent (2003); Sutton (2009); } \\
\text { Arnaboldi and Lapsley (2009) }\end{array}$ \\
\hline Accountability & $\begin{array}{ll}\text { 1. } & \text { Financial accountability } \\
\text { 2. } & \text { Managerial accountability }\end{array}$ & 0.610 & $\begin{array}{llr}\text { Institutional } & \text { theory } & \text { and } \\
\text { different } & \text { forms } & \text { of } \\
\text { accountability } & & \end{array}$ & $\begin{array}{l}\text { Chi-chi } \quad \text { and } \\
\text { Ebimobowei(2012); Vamosi } \\
(2005) ; \text { Samkin and Schneider, } \\
2010\end{array}$ \\
\hline
\end{tabular}




\section{Hypotheses testing}

The study has applied multiple linear regression analysis to test the statistical relationships between the independent and dependent variables. ANOVA has been applied to test the significance of the models and variables. The dependent and independent variables in this study are classified in two levels.

\section{Level 1:}

Independent variables were technology, pressure from the NBAA, pressure from donors, demographic/human resource factors, pressure from audit, political will, training, management support, regulatory matter, culture of transparency and management change.

Dependent variable was an effective implementation of accrual accounting

\section{Level 2:}

Independent variable was an effective implementation of accrual accounting.

Dependent variable was the level of managerial accountability.

Level 1. Dimensions of factors associated with institutional, social and individual related aspects are positively influencing the effective implementation of accrual accounting.

Table 2: Model summary

\begin{tabular}{|l|r|r|r|r|r|}
\hline Model & \multicolumn{1}{|c|}{$\mathrm{R}$} & R Square & $\begin{array}{c}\text { Adjusted R } \\
\text { Square }\end{array}$ & $\begin{array}{c}\text { Std. Error of the } \\
\text { Estimate }\end{array}$ & Durbin-Watson \\
\hline 1 & $.627^{\mathrm{a}}$ & .393 & .358 & .42396 & 1.534 \\
\hline
\end{tabular}


The model summary in table 2 shows that $\mathrm{R}=0.627$, which implies that there is a strong positive relationship between the dimensions of factors associated with institutional, social and individual related aspects (i.e. technology, demographic/technical factors, regulatory matters, training, management support, pressure from donor, pressure from the NBAA, culture of transparency, political will, management change commitment, and pressure from auditing) and an effective implementation of accrual accounting. The adjusted $\mathrm{R}$ square of 0.358 shows that the $35.8 \%$ proportion of variances in the effective implementation of accrual accounting is explained by technology, demographic/technical factors, regulatory matters, training, management support, pressure from donor, pressure from the NBAA, culture of transparency, political will, management change and pressure from auditing. The remaining $64.2 \%$ is explained by other factors, which are not covered in this study.

Durbin Watson has been used to test a serial correlation among the residuals, which range from 0 to 4 . It is a rule of thumb that Durbin Watson residuals ranging from 0 to 2 depict no correlation, and Durbin Watson residuals above 2 depict correlation. Our findings have revealed Durbin Watson of 1.534. This provides evidence that there is no autocorrelation among successive error terms.

Table 3: ANOVA test

\begin{tabular}{|l|r|r|r|r|r|}
\hline Model & Sum of Squares & df & Mean Square & F & Sig. \\
\hline 1 Regression & 22.313 & 11 & 2.028 & 11.285 & $.000^{\mathrm{a}}$ \\
Residual & 34.511 & 192 & .180 & & \\
Total & 56.824 & 203 & & & \\
\hline \\
a. Predictors: (constant), technology, pressure from the NBAA, pressure from \\
donors, demographic factors, audit, political will, training, management support, \\
legal, culture and management change \\
b. Dependent Variable: effective implementation of accrual accounting \\
\hline
\end{tabular}

H1: Institutional and societal factors are positively influencing the effective implementation of accrual accounting.

\section{Operational hypotheses}


H1a: Pressures from donors are positively influencing the effective implementation of accrual accounting.

Our findings (table 4) support H2a, which states that donors' pressures are positively influencing the effective implementation of accrual accounting. This support is based on both unstandardised and standardised coefficients, which are 0.285 and 0.357 respectively at the significant level of 0.000 . The findings revealed the role that donors' pressures can play in the implementation of accrual accounting in emerging economies. Extant work in public sector accounting in emerging economies states that technocrats tend to respond to donors' pressures by manipulating legitimacy (Adhikari et al., 2013; Goddard et al., 2016). Their responses help them get access to external funding but rarely will there be any positive impact in the efficiency and effectiveness of organisations' operations (Kurunmaki et. al., 2003; Meyer and Rowen, 1997). Such is more striking in contexts experiencing resource scarcity and environmental uncertainty (Luder, 1992; Collier, 2001; Goddard and Mzenzi, 2015). Our findings are, however, more consistent with Mbelwa (2015), along with the assumptions of institutional theory that coercive and normative pressures from donors can bring positive results to internal efficiency and effectiveness of an organisation's operations in some contexts (Meyer and Rowen, 1977; DiMaggio and Powell, 1983). Donors' pressures may therefore result in diverse consequences in the implementation of accrual accounting in the public sector of emerging economies.

\section{H1b: Pressures from the National Board of Accountants and Auditors (NBAA)}

Our findings (table 4) support H2a, which asserts that pressures from the NBAA are positively influencing the effective implementation of accrual accounting, with unstandardised and standardised coefficients of 0.137 and 0.147 respectively at the insignificant level of 0.076 . Although the positive influence of the NBAA on the effective implementation of accrual accounting has been noted, the influence is, however, less than what is expected given the existence of the National Professional Board of Accountants and Auditors in the country. Public sector accountants and auditors are envisaged as catalysts of accounting changes in prior studies (Hyndmann and Connolly, 2011; Adhikari et al., 2013). Our findings also delineate a relatively low degree of coercive, normative and mimetic pressures being executed by the NBAA, thereby signalling the ineffectiveness as well as the minimal role of the Board in 
discharging its regulatory functions to public sector entities. This result is consistent with the observation made by Goddard and Mzenzi (2013).

H1c: Political will is positively influencing the effective implementation of accrual accounting.

The findings (table 4) have rejected $\mathrm{H} 2 \mathrm{a}$, which asserts that political will positively influences the effective implementation of accrual accounting, on the basis of unstandardised and standardised coefficients -0.168 and -0.196 respectively at the significant level of 0.017 . This posits the political unwillingness of stakeholders in implementing accrual accounting. There is apparently a political resistance instigated by a lack of awareness amongst boards and other committees, such as the parliamentary public audit committee, of what accrual information can bring to the public sector and the implementation mechanisms of accrual accounting (Ahmad, 2016). That political unwillingness can be a key obstacle in implementing accrual accosting is also evident in prior work (Ahmad, 2016); Goddard \& Mzenzi, 2013; Goddard and Malagila, 2015; Mkasiwa, 2011). Political unwillingness tends to increases uncertainty and results in symbolic compliance (Arnaboldi and Lapsley, 2009).

H1d: Management changes are positively influencing the effective implementation of accrual accounting

The findings (table 4) have revealed an insignificant level of positive influence of management changes in the effective implementation of accrual accounting, with unstandardised and standardised coefficients of 0.003 and 0.004 respectively and at the significant level of 0.036 . This shows little willingness amongst technocrats to initiate changes for the implementation of accrual accounting. This also implies that the degree of changes on the side of technocrats and managers is relatively lower than what is expected for the effective implementation of accrual accounting (Luder, 1992; Ahmad, 2016). The findings also signal the existence of conflicts and tension with regard to the appropriateness of accrual accounting in government entities. Ambiguities in defining accrual accounting, as is the case in other countries (Adhikari and Gårseth-Nesbakk, 2016), along with multiple interpretations have impaired the effectiveness of accrual information and undermined the consistency in financial reporting (Arnaboldi and Lapsley, 2009). The key actors involved in accrual accounting changes have exploited policy ambiguities by obstructing, delaying and blocking changes that are not in their interest. In such 
circumstances, the prevalence of the symbolic, experimental and politically-oriented model of accrual basis accounting is inevitable.

Hle: Auditing pressures are positively legitimising the effective implementation of accrual accounting.

The findings (table 4) support H2f stating auditing pressures are positively influencing the effective implementation of accrual accounting, with unstandardised and standardised coefficients of 0.195 and 0.162 respectively at the significant level of 0.046 . The important role that auditing pressures can play in the implementation of accrual accounting is striking in the findings. Internal and external auditing coupled with institutional pressures contributes to the effective operationalisation of accrual accounting. It is argued that public auditing can be an important source of normative, mimetic and coercive pressure that links actors and organisation processes with the specific objectives of accrual accounting (Hay and Cordery, 2018). Audit reports and recommendations are prerequisite to obtain resources from the basket fund of international organisations (Mbelwa, 2015; Goddard and Malagila, 2015). In this regard, the findings underpin the very ideas of institutional theory (DiMaggio and Powell, 1983), which posit that coercive and normative pressures associated with auditing have the potential to enhance efficiency and effectiveness in organisations' operations. In such circumstances, the blending of the administrative-experimental models of accrual accounting is likely to prevail.

\section{H1g: Regulatory matters are positively legitimising the effective implementation of accrual accounting.}

The findings (table 4) reject $\mathrm{H} 2 \mathrm{a}$, which asserts that regulatory matters are positively influencing the effective implementation of accrual accounting, with unstandardised and standardised coefficients of -0.110 and -0.144 respectively at the significant level of 0.128 . This result delineates how regulatory deficiencies in the public sector can impact on the implementation of accrual accounting (Goddard and Mzenzi, 2013). That public sector accounting in Tanzania is highly regulated by the Government and donors is discussed in prior work (Goddard et al., 2016). A lack of harmonisation of existing accounting laws and regulations in the country, inconsistency in their application and the pursuit of outdated accounting provisions have all added to further challenges and instigated conflicts in the implementation of accrual accounting (Goddard and Mzenzi, 2015). Such adverse regulatory 
influences, as identified in Tanzania, are consistent with the findings of Chalu (2007), Mbelwa (2015), and Goddard and Mzenzi (2013). Our results reinforce the existence of a symbolicexperimental model contributing to the ineffective implementation of accrual accounting.

\section{H1h: Culture of transparency is positively legitimising the effective implementation of accrual accounting.}

The findings (table 4) support H2a stating that the culture of transparency is positively influencing the effective implementation of accrual accounting, with unstandardised and standardised coefficients of 0.115 and 0.111 respectively, but with the insignificant level of 0.313. This finding indicates the existence of a rather unfriendly administrative and political culture toward the implementation of accrual accounting. This also implies that the existing culture has a more limited degree of openness than is required for the effective implementation of accrual accounting (Luder, 1992). In such situations, the political and administrative culture of information producers is negatively correlated with the need for more informative governmental accounting data and accrual-based financial reporting (Luder, 1992; Mbelwa, 2015). This result further affirms the presence of the ineffective administrative model of implementing accrual accounting in the country.

\section{H2: Institutional and individual related factors are positively dominating the effective implementation of accrual accounting}

Operational hypotheses

\section{H2a: Human resources/individual actors' related aspects are positively dominating the effective implementation of accrual accounting}

The findings (table 4) are inconsistent with $\mathrm{H} 2 \mathrm{a}$, which states that human resources/individual actor-related factors are positively influencing the effective implementation of accrual accounting. The results are based on the unstandardised and standardised coefficients of -0.252 and -0.292 respectively at the significant level of 0.000 . This means the more individual actors/technocrats are educated, skilled and experienced, the more ineffective they are in the implementation of accrual accounting. In this regard, the present study is inconsistent with those undertaken by Chalu (2007) and the IFAC (2011), in which assertions are made that 
qualified individuals (administrators/managers) tend to play more critical roles in the implementation of accrual accounting. Askim (2009) further states that the most educated councillors/political actors are least inclined to use performance information based on accrual information. Such contradictory findings may shed light on the existence of political resistance in the forms of a loose coupling between formal structures and actual practices (Goddard and Mzenzi, 2013; Goddard and Malagila, 2015; Goddard and Mkasiwa, 2016) in the implementation of accrual accounting. Moreover, the results delineate the existence of an unfavourable institutional environment enabling the technocrats to apply their knowledge, experience and skills, and manipulate the implementation of accrual accounting for external reporting, with minimal impact on internal effectiveness and efficiency (Kurunmaki et. al., 2003; Goddard and Mzenzi, 2015). This may also result in the existence of an ineffective administrative model for implementing accrual accounting.

H2b: The availability of technology is positively used to standardise the effective implementation of accrual accounting.

The findings (table 4) reject $\mathrm{H} 2 \mathrm{a}$, which states that the availability of technology positively influences the effective implementation of accrual accounting, with unstandardised and standardised coefficients of 0.048 and 0.042 respectively at the significant level of 0.515 . This result demonstrates how the limited availability of accounting information, as well as the prevalence of incompatible accounting information, impacts on the implementation of accrual accounting. Prior work illustrates the importance of having advanced IT systems, accounting software, and technicians for the adoption of accrual accounting (Kasim, 2015; Lassou and Hopper, 2016). A lack of IT support and ICT equipment essential for the implementation of accrual accounting is perhaps not a surprise in the public sector due to financial constraints. In the absence of innovation and IT technology in the central government of Tanzania, the ineffective symbolic-experimental model of implementation of accrual accounting has continued to prevail.

H2c: The availability of training is positively dominating the effective implementation of accrual accounting.

The findings (table 4) supported $\mathrm{H} 2$ stating that the availability of training is positively influencing the effective implementation of accrual accounting, with unstandardised and 
standardised coefficients of 0.340 and 0.467 respectively, at the significant level of 0.000 . The result reveals how the related provisions of customized training to technocrats in the organisation influences the administrative model of implementing accrual accounting. Such is clearly evident in contingency theory and the model developed by Luder (1992). In this model, mentions are made that the training of technocrats has the potential to alter their attitudes towards accrual accounting, so that they might be willing to embrace changes and facilitate implementation of accrual accounting. This may help create the effective models for the administrative implementation of accrual accounting in the public sector.

H2d: Management supports are positively dominating the effective implementation of accrual accounting

The findings (table 4) have rejected $\mathrm{H} 2$ a stating that managerial support positively influences the effective implementation of accrual accounting, with unstandardised and standardised coefficients of -0.019 and -0.027 respectively at the insignificant level of 0.766 . The results imply that there is a lack of management support, both from financial and non-financial aspects, to implement accrual accounting in ministries and departments. Management support in the study has been defined on the basis of established structures and systems, as well as the presence of explicit regulations required for the implementation of accrual accounting within government entities (Luder, 1992; Scapens, 2006; Chalu, 2007; Taipaleenmaki and Ikaheimo, 2013). However, it can be argued that the management support has not been well articulated in government ministries as a result of the implementation of the symbolic and political-oriented model of accrual accounting.

Table 4 depicts the regression model applied in the study and significantly predicts the dependent variables (the effective implementation of accrual accounting). Given that the significance of the model is less than 0.05 , it generally implies that it can predict the dependent variable.

\section{Table 4: Coefficients}




\begin{tabular}{|c|c|c|c|c|c|c|}
\hline \multirow{2}{*}{\multicolumn{2}{|c|}{ Models }} & \multicolumn{2}{|c|}{$\begin{array}{c}\text { Unstandardised } \\
\text { coefficients }\end{array}$} & \multirow{2}{*}{\begin{tabular}{|c|}
$\begin{array}{c}\text { Standardised } \\
\text { coefficients }\end{array}$ \\
Beta \\
\end{tabular}} & \multirow[b]{2}{*}{$\mathrm{t}$} & \multirow[b]{2}{*}{ Sig. } \\
\hline & & B & Std. Error & & & \\
\hline \multirow[t]{12}{*}{1} & (Constant) & 2.002 & .403 & & 4.965 & .000 \\
\hline & Mgt support & -.019 & .063 & -.027 & -.298 & .766 \\
\hline & Mgt change & .003 & .098 & .004 & .036 & .972 \\
\hline & Legal & -.110 & .072 & -.144 & -1.529 & .128 \\
\hline & Culture & .115 & .114 & .111 & 1.011 & .313 \\
\hline & $\begin{array}{l}\text { Pressure from the } \\
\text { NBAA }\end{array}$ & .137 & .077 & .147 & 1.782 & .076 \\
\hline & Political will & -.168 & .069 & -.196 & -2.418 & .017 \\
\hline & $\begin{array}{l}\text { Demographic } \\
\text { factors }\end{array}$ & -.252 & .060 & -.298 & -4.223 & .000 \\
\hline & Training & .340 & .054 & .467 & 6.312 & .000 \\
\hline & Audit & .195 & .097 & .162 & 2.013 & .046 \\
\hline & $\begin{array}{l}\text { Pressure from } \\
\text { donor }\end{array}$ & .285 & .052 & .357 & 5.489 & .000 \\
\hline & Tech & -.048 & .073 & -.042 & -.652 & .515 \\
\hline
\end{tabular}

Drawing on the unstandardised coefficients from table 4, the regression model for this study is as follows:

Eff.Impl.ACC $=2.002+0.285 \mathrm{PD}+0.137 \mathrm{PN}+0.115 \mathrm{C}+0.195 \mathrm{PA}+0.340 \mathrm{~T}+0.003 \mathrm{MC}-$ 0.019MS - 0.110L- 0.168PW - 0.252Demo- 0.048techs

Where by Eff.Impl.ACC $=$ Effective implementation of accrual accounting

$$
\begin{gathered}
\mathrm{PD}=\text { Pressure from donor } \\
\mathrm{PN}=\text { Pressure from NBAA } \\
\mathrm{C}=\text { Culture of transparency } \\
\mathrm{PW}=\text { Political will } \\
\mathrm{MS}=\text { Management support }
\end{gathered}
$$




$$
\begin{aligned}
& \mathrm{T}=\text { Training } \\
& \mathrm{MC}=\text { Management change } \\
& \mathrm{PA}=\text { Pressure from auditing } \\
& \text { Legal }=\text { Regulatory matters } \\
& \text { Demo }=\text { Demographic or technical factor } \\
& \text { Techs }=\text { Level of technology }
\end{aligned}
$$

From this model the following can be deduced:

\section{Level 2}

H2: The effective implementations of accrual accounting positively influence the level of managerial accountability.

Table 5: Model summary for level 2 hypotheses

\begin{tabular}{|l|r|r|r|r|r|}
\hline Model & \multicolumn{1}{|c|}{$\mathrm{R}$} & R Square & $\begin{array}{c}\text { Adjusted R } \\
\text { Square }\end{array}$ & $\begin{array}{c}\text { Std. Error of the } \\
\text { Estimate }\end{array}$ & Durbin-Watson \\
\hline 1 & $.355^{\mathrm{a}}$ & .126 & .122 & .37609 & 1.233 \\
\hline
\end{tabular}

Table 5 shows $\mathrm{R}$, which is a correlation of the model of about $35.5 \%$, as the highest degree of correlation that measures the quality of the prediction in the dependent variable (managerial accountability), and $12.6 \%$ of adjusted $\mathrm{R}$ square which shows the closeness of data to the regression line. The adjusted $\mathrm{R}$ square for $12.6 \%$ explained the variation in the linear regression model as well as the strength of relationship between the model and the variable. This model shows that a $12.6 \%$ proportion of variance in the managerial accountability (dependent) can be explained by the effective implementation of accrual accounting. The remaining $87.4 \%$ is explained by other factors not covered in this study. Also, the model has a Durbin Watson of 1.233, which implies that there is no autocorrelation among successive error terms.

Table 6: ANOVA table for level 2 hypotheses 


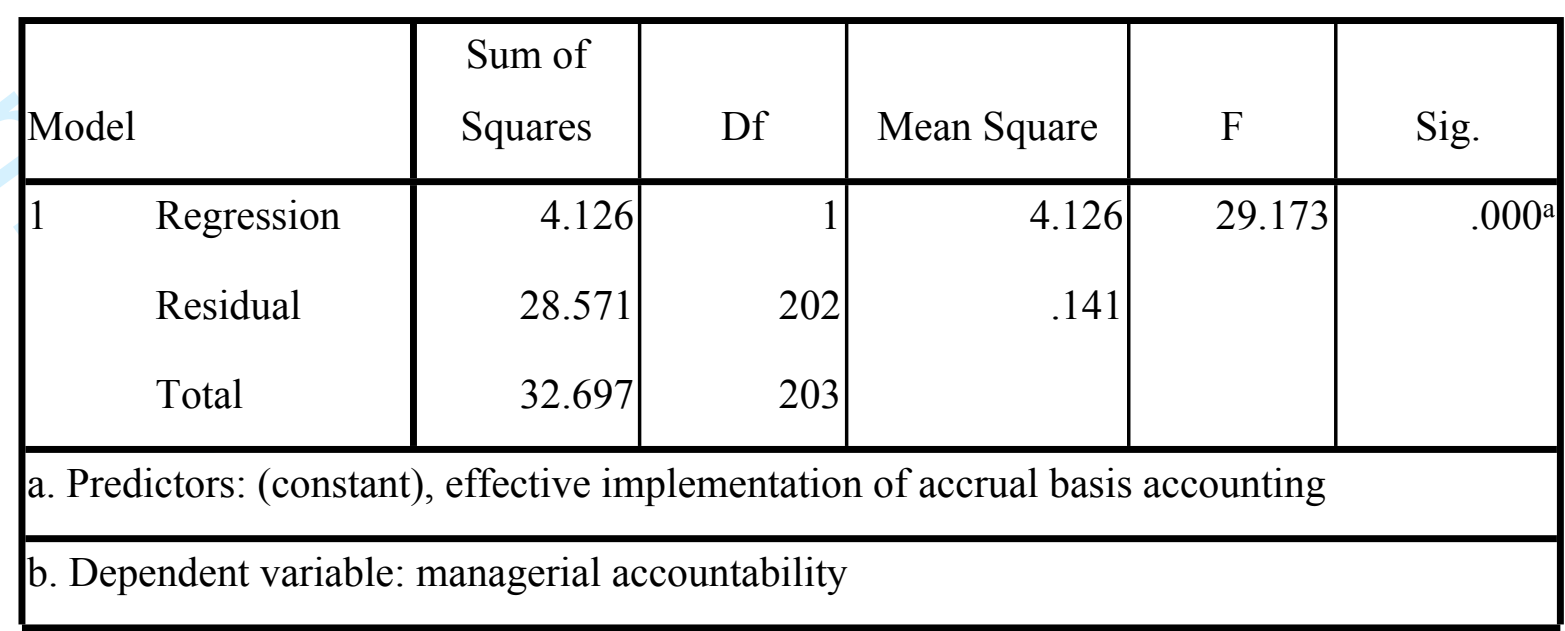

Table 6 demonstrates that the regression model applied significantly predicts the dependent variable (managerial accountability) by indicating the significance of the mode, which is less than 0.05 .

Table 7: Coefficient for level 2 hypotheses

\begin{tabular}{|c|c|c|c|c|c|}
\hline \multirow[b]{2}{*}{ Model } & \multicolumn{2}{|c|}{ Unstandardised coefficients } & \multirow{2}{*}{$\begin{array}{c}\begin{array}{c}\text { Standardised } \\
\text { coefficients }\end{array} \\
\text { Beta }\end{array}$} & \multirow[b]{2}{*}{$\mathrm{t}$} & \multirow[b]{2}{*}{ Sig. } \\
\hline & B & Std. Error & & & \\
\hline $\begin{array}{ll}1 & \text { (Constant) } \\
& \text { effective } \\
\text { implementation } & \\
\text { of accrual }\end{array}$ & $\begin{array}{r}2.364 \\
.269\end{array}$ & .214 & .355 & $\begin{array}{r}11.061 \\
5.401\end{array}$ & $\begin{array}{l}.000 \\
.000\end{array}$ \\
\hline
\end{tabular}

Table 7 demonstrates the information for predicting managerial accountability as the outcome of the predictor, for instance, the effective implementation of accrual accounting. By using the standardised coefficient from table 7 , we have deduced the following equation/model:

Managerial accountability $=2.364+0.355$ effective administrative implementation model of accrual accounting. 
Following the above equation, the effective implementation of accrual accounting has been identified as $5 \%$ significant. This implies that for every $100 \%$ change in the effective implementation of accrual basis accounting, 35.5\% of the results apply to managerial accountability. This indicates a positive relationship between dependent and independent variables. Our findings reveal that the effective implementation of accrual accounting is positively/significantly related to the level of managerial accountability. These findings are in line with the study conducted by Bastani et al. (2012), which concerns with the role of accrual accounting and reporting in promoting transparency and accountability. Bastani et al. (2012) propagate a view that accrual accounting implementation enhances accountability and transparency.

\section{Concluding remarks}

Prior work discussing public sector accounting reforms in emerging economies has drawn critics on international organisations such as the World Bank and the IMF for exerting various forms of institutional pressures - coercive, mimetic and normative - for the adoption of accrual accounting and the Cash Basis IPSAS, the significance of which are continually being questioned in western countries, let alone emerging economies. It is argued that there has been a misleading and partial understanding about accrual accounting at institutional level, not least in emerging economies, assuming it more of a technical accounting reform (Hepworth, 2015; Wall and Connolly, 2016; Adhikari and Gårseth-Nesbakk, 2016). As a result, the involvement of professional accountants, consultants and big auditing firms has been emphasised, which has further complicated accrual accounting reforms across countries instigating a power struggle between policy makers and the accounting profession (Christensen et al., 2018). Such is clearly evident in a range of emerging economies, including Sri Lanka (Adhikari et al., 2013), Nepal (Adhikari and Jayasinghe, 2017), Bangladesh (Salah et al., 2018), as well as in a large number of African countries (Hopper et al., 2017; Lassou and Hopper, 2016). In fact, the findings of recent studies conducted in Africa demonstrate that public sector accounting reforms, primarily accrual accounting, have almost dismantled the existing public finance system and further weakened governance by promoting corruption, patronage politics and neopatrimonialisms (Bakre et al., 2017; Goddard et al., 2016; Nyamori et al., 2017; Hopper, 2017). Voices are echoed calling for the rethinking of government accounting reforms in Africa restoring participatory and incremental mechanisms and appreciating indigenous solutions. Hepworth (2017, p. 142) states that accrual accounting reforms have increasingly proved to be 
a massive management reform, not least in emerging economies, requiring a cultural shift, financial awareness, well-developed accounting infrastructure and human capital, and a collaborative environment in which managers and government accountants can work together to achieve efficiency and effectiveness in resource mobilisation and service delivery (Hepworth, 2017, p. 142).

This study of accrual accounting in the central government of Tanzania perhaps serves as evidence delineating the challenges inherited to accrual accounting and the factors stifling its successful implementation. As is the case in other emerging economies (Harun et al., 2012; Adhikari et al., 2013), coercive, memetic and normative institutional pressures have predominated accrual accounting reforms in Tanzania, the country being one of the few emerging economies adopting accrual accounting and IPSASs for central government accounting and reporting. The normative benefits of accrual accounting propagated by donors and international organisations through various coercive mechanisms, such as loan conditionality (DiMaggio and Powell, 1983; Meyer and Rowan, 1977; DiMaggio, 1991) and the assertion that accrual accoutring would improve overall governance and economy of Tanzania, triggered accrual accounting reforms, which culminated in 2013 with the enforcement of accrual accounting across central government entities (URT, 2014; Goddard et al., 2016). However, factors such as weak pressures from the National Board of Accountants and Auditors, inadequate political will, management support and changes, poor auditing, ineffective regulatory mechanisms, along with a lack of a culture of transparency, adequate training and capacity development have adversely affected managerial accountability in the country (Keay, 2017; Mehr, 2015), making accrual accounting ineffective in practice. Our findings show the continuity of unfavourable institutional and organisational environments, offering the technocrats and other government officials the opportunity to manipulate the implementation of accrual accounting. Discernible impacts of accrual accounting in improving overall efficiency and effectiveness in resource mobilisation and service delivery is almost nonexistent. Our results therefore posit the fact that an ineffective and ceremonial model of administrative implementation of accrual accounting is taking place in the central government of Tanzania.

Given the poor enforcement of accrual accounting, our findings also reflect a limited potency of coercive, normative and mimetic pressures at the implementation stage as compared with the adoption stage of accrual accounting. This argument has been drawn observing the minimal 
role that the NBAA has discharged in being a regulatory entity for public sector entities. Unlike many other emerging economies, Sri Lanka serving as an example (Adhikari et al., 2013), accrual accounting has attracted less attention of professional accountants and auditors and their engagement in the implementation process has remained marginal. As a result, issues relating to technology advancement and human resource development so as to cope with accrual accounting are virtually absent at policy level. The administrative model of accrual accounting implemented in the central government of Tanzania has therefore provided the technocrats and government officials with a space for manipulating financial information to external institutional environments and to obtain legitimacy and resources rather than increase efficiency and effectiveness at organisational level.

Out study contributes to extant public accounting work by presenting a unique emerging economy case in which accrual accounting has been actually put into effect, but the implementation has been marred by a struggle for conformance. Unlike other emerging economies (see e.g. Salah et al., 2018), resistance to accrual accounting reforms or a replacement of accrual accounting with other reform approaches, such as the Cash Basis IPSAS, has not been a feature of public sector accounting reforms taking place in Tanzania. The implementation of accrual accounting has been largely manipulated in the central government of Tanzania, further jeopardising governance and accountability, as is evident in other African countries (Bakre et al., 2017; Hopper, 2017; Hopper et al., 2017; Hopper and Lassou, 2016; Nyamori et al., 2017). Our findings also reinforce the underlying intention of international organisations to promote accrual accounting reforms in emerging economies (Hopper et al., 2017). In promoting such technical reforms in emerging economies, not only are these organisations justifying their public finance expertise, but they are also fulfilling their lending requirements and securing employment for their consultants. That their focus is solely on the adoption of reforms by emerging economies rather than their implementation is clearly reflected in our findings. Theoretically, this paper argues that the individual factors in conjunction with the institutional aspects are produced and reproduced as means of domination or standardise the accrual practice into the public sector context whereas the societal and other institutional factors legitimise the practice of accrual accounting. The extent of the managerial accountability and decision-usefulness measures the effectiveness of the factors in implementation of accrual accounting. 
To sum up, combining the ideas of institutional theory and decision-usefulness, we have in this study illustrated the factors that could constrain the implementation of accrual accounting at the organizational level of emerging economies. On the whole, what is important is to understand that accrual accounting is more of a management reform, incorporating changes in broader aspects of institutional and accountability mechanisms, rather than just an adoption of particular accounting technologies. However, the context of each emerging economy is different, as they vary in terms of colonial history, social-political environment, and the engagement of the accounting profession and education (Van Helden and Uddin, 2016). We therefore call for future studies on accrual accounting in other emerging economies so as to extend our understanding of the constraining factors in implementing such technical accounting reforms, the way international organisations have persuaded emerging economies to advance for these reforms and the actual implementation of accrual accounting incorporating the agencies of different stakeholders, not least professional accountants.

\section{References}

Adhikari, P. and Gårseth-Nesbakk, L. (2016), "Implementing public sector accruals in OECD member states: Major issues and challenges”, Accounting Forum, Vol. 40 No. 2, pp. 125-142.

Adhikari, P. and Jayasinghe, K. (2017), ““Agents-in-focus' and 'Agents-in-context': the strong structuration analysis of central government accounting practices and reforms in Nepal”, Accounting Forum, Vol. 41 No. 2, pp. 96-115.

Adhikari, P. and Mellemvik, F. (2010), "The adoption of IPSASs in South Asia: A comparative study of seven countries", Research in Accounting in Emerging Economies, Vol. 10, pp. 169-199.

Adhikari, P. and Mellemvik, F. (2011), “The rise and fall of accruals: a case of Nepalese central government", Journal of Accounting in Emerging Economies, Vol. 1 No. 2, pp. 12343.

Adhikari, P., Kuruppu, C. and Matilal, S. (2013), "Dissemination and institutionalization of public sector accounting reforms in less developed countries: a comparative study of the Nepalese and Sri Lankan central governments", Accounting Forum, Vol. 37 No. 3 , pp. 213-230. 
Adhikari, P., Kuruppu, C., Wynne, A. and Ambalangodage, D. (2015), "Diffusion of the Cash Basis International Public Sector Accounting Standard (IPSAS) in Less Developed Countries (LDCs) -The Case of the Nepali Central Government", Research in Accounting in Emerging Economies, Vol. 15, pp. 85-108.

AGD. (2015a). Practical implementation experience of IPSAS Accrual Basis - Tanzania Case, Tanzania.

AGD. (2015b). Transition to the Accrual Basis of Accounting: Guidance for Public Sector, Tanzania.

Ahmad, N.N. (2016), "Investigationg the factors influencing users' resistance towards accrual accounting", Procedia Economic and Finance, Vol. 35, pp. 17-26.

Ahn, P., Jacobs, K., Lim, D. W. and Moon, K. (2014), "Beyond self-evident: Recognising the problematic political context of accrual accounting adoption in South Korea", Financing, Accounting \& Management. Vol. 30 No. 1, pp. 25-48.

Alawattage, C., Hooper, T. and Wickramasinghe, D. (2007), "Introduction to management accounting in less developed countries", Journal of Accounting \& Organizational Change, Vol. 3 No. 3, pp. 183-191.

Al-Maskari, A. and Sanderson, M. (2011), "The effect of user characteristics on search effectiveness in information retrieval', Information Processing and Management, Vol. 47, pp. 719-729.

Arnaboldi, M. and Lapsley, I. (2009), “On the Implementation of Accrual Accounting: A Study of Conflict and Ambiguity", The European Accounting Review, Vol. 18 No. 4, pp. 809836.

Askim, J. (2009), “The demand side of performance measurement: explaining councillors' utilization of performance information in policymaking”, International Public Management Journal, Vol. 12 No. 1, pp. 24-27.

Athukorala, S. and Reid, B. (2003), Accrual Budgeting and Accounting in Government and Its Relevance for Developing Countries, Asian Development Bank, Manila.

Bakre, O., Lauwo, S. and McCartney, S. (2017), "Western accounting reforms and accountability in wealth redistribution in patronage-based Nigerian society", Accounting, Auditing \& Accountability Journal. Vol. 30 No. 6, pp. 1288-1308.

Ball, I. (2012), "New development: transparency in the public sector", Public Money \& Management, Vol. 32 No. 1, pp. 35-40. 
Ball, I. and Pflugrath, G. (2012), “Government accounting: Making Enron look good”, World Economics, Vol. 13 No. 1, pp. 1-18.

Baradyana, J. and Ame, A. (2005), Quantitative Techniques for Business Decisions, Mkuki na Nyota Publishers 1td, Dar es Salaam.

Barton, A. (2009), "The use and abuse of accounting in the public sector financial management reform program in Australia", ABACUS, Vol. 45 No. 2, pp. 221-248.

Bastani, P., Abolhalaj, M., Jelodar, H. M., and Ramezanian, M. (2012), "Role of accrual accounting in report transparency and accountability promotion in Iranian public health sector”, Middle East Journal of Scientific Research, Vol. 12 No. 8, pp. 1097-1101.

Beaver, W.H. (1998), Financial Reporting: An Accounting Revolution, Prentice-Hall, NJ.

Beest, F., Braam, G. and Boelens, S. (2009), Quality of Financial Reporting: Measuring Qualitative Characteristics, Nijmegen Center for Economics (NiCE), Institute for Management Research, Radboud University Nijmegen.

Bogt, H. (2008), "Recent and future management changes in Local Government: Continuing focus on rationality and efficiency?", Financial Accountability \& Management, Vol. 24 No. 1, pp. 31-57.

Bruno, A. and Lapsley, I. (2018), “The emergence of an accounting practice: The fabrication of a government accrual accounting system", Accounting, Auditing \& Accountability Journal, Vol. 31 No. 4, pp. 1045-1066.

Bruns, W. (1968), "Accounting information and decision-making: Some behavioural hypotheses". The Accounting Review, Vol. 43 No. 3, pp. 469-480.

Brusca, I., Gomez-Villegas, M. and Montesinos, V. (2016), "Public finance management reforms: the role of IPSAS in Latin-America", Public Administration and Development, Vol. 36 No. 1, pp. 51-64.

Carpenter, V.L. and Feroz, E. H. (2001), “Institutional theory and accounting rule choice: An analysis of four US state governments' decisions to adopt generally accepted accounting principles", Accounting, Organization and Society, Vol. 26 No. 7/8, pp. 565-596.

Carruthers, B. (1995), “Accounting, ambiguity, and the new institutionalism”, Accounting, Organizations and Society, Vol. 20 No. 4, pp. 313-328.

Cavanagh, J., Flynn, S. and Moretti, D. (2016), Implementing Accrual Accounting in the Public Sector, Fiscal Affairs Department, IMF, Washington DC.

Chalu, H. (2007), “Analysis of stakeholder factors influencing the effectiveness of accounting information systems in Tanzania local luthorities", Business Management Review. Vol. 
16 , pp. $18-48$.

Chi-Chi, O.A and Ebimobowei, A. (2012), "Fraudulent activities and forensic accounting services of banks in Port Harcourt Nigeria", Asian Journal of Business Management, Vol. 4 No. 2, pp.124-129.

Christensen, M., Newberry, S. and Potter, B. (2018), “Enabling global accounting change: epistemic communities and creation of a 'more business-like' public sector", Accounting, Auditing \& Accountability Journal, in press.

Churchill, M. (1992), "Accrual accounting in the public sector", Australian Accountant, Vol. 62 No. 5, pp. 39.

Cohen, S., Kaimenaki, E., and Zorgios, Y. (2007), “Assessing IT as a key success factor for accrual accounting implementation in Greek mulicipalities", Financial Accountability \& Management, Vol. 23 No. 1, pp. 91-111.

Collier, P. (2001), "The power of accounting: a field study of local financial management in a police force", Management Accounting Research, Vol. 12 No, 4, pp. 465-486.

Coy, D., Fischer, M. and Gordon, T. (2001), "Public accountability: a new paradigm for college and university annual reports", Critical Perspectives on Accounting, Vol. 12 pp. 1-31.

Dillon, S., Buchanan, J. and Corner, J. (2010), Comparing public and private sector decision making: problem structuring and information quality issues, Proceedings of the 45 th Annual Conference of the ORSNZ, New Zealand, November 29-30.

DiMaggio, P. (1991), Constructing an organizational field as a professional project: The case of US art museums. In Powell, W.W. and DiMaggio, P. (Eds.), Institutional Theory in Organizationa Studies, The University of Chicago Press, Chicago, pp. 267-292.

DiMaggio, P. J. and Powell, W. W. (1983), “The iron cage revisited: Institutional isomorphism and collective rationality in organizational fields", American Sociological Review, Vol. 48 No. 2, pp. 147-160.

Ellwood, S. and Newberry, S. (2007), "Public sector accrual accounting: institutionalising neo-liberal principles?", Accounting, Auditing \& Accountability Journal, Vol. 20 No. 4, pp. 549-573.

Ezzamel, M., Hyndman, N., Johnsen, A. and Lapsley, I. (2014), "Reforming central government accounting: an evaluation of an accounting innovation", Critical Perspectives on Accounting, Vol. 25 No. 4/5, pp. 409-422.

Federation of European Accountants (FEE). (2007), Accrual Accounting in the Public Sector, Brussels. 
Gibassier, D. (2017), “From écobilan to LCA: The elite's institutional work in the creation of an environmental management accounting tool”, Critical Perspectives on Accounting, Vol. 42, pp. 36-58.

Goddard, A. (2010), "Contemporary public sector accounting research - An international comparison of journal papers", British Accounting Review, Vol. 42 No. 2, pp. 75-87.

Goddard, A. and Mkasiwa, T. A. (2016), "New public management and budgeting practices in Tanzanian Central government: struggling for conformance", Journal of Accounting in Emerging Economies, Vol. 6 No. 4, pp. 340-371.

Goddard, A. and Mzenzi, S. I. (2013), Accounting Practices in Tanzania Local Government Authorities: Towards a Grounded Theory of Manipulating Legitimacy, University of Southampton.

Goddard, A. and Malagila, J. (2015), "Public sector external auditing in Tanzania: a theory of managing colonising tendencies", Research in Accounting in Emerging Economies, Vol. 15, pp. 179-222.

Goddard, A., Assad, M., Issa, S. and Malagila, J. (2016), “The two publics and institutional theory-a study of public sector accounting in Tanzania”, Critical Perspectives on Accounting, Vol. 40 October, pp. 8-25.

Gomes, D., Carnegie, G. D. and Rodrigues, L. (2008), “Accounting change in central government", Accounting, Auditing \& Accountability Journal, Vol. 21 No. 8, pp. 11441184.

Green, S. (1991), "How many subjects does it take to do a regression analysis?", Multivariate Behavioral Research, Vol. 26, pp. 499-510. Guthrie, J. (1998), “Application of accrual accounting in the Australian public sector - rhetoric or reality?", Financial Accountability \& Management, Vol. 14 No. 1, pp.1-19.

Guthrie, J., Humphey, C. and Olson, O. (1999), "Debating developments in new public financial management: the limits of global theorising and some new ways forward", Financial Accountability \& Management, Vol. 15 No. (3-4), pp. 209-228.

Hair, J., Black, W., Babin, B. and Anderson, R. (2010), Multivariate Data Analysis: Global edition (7th ed.), Pearson Higher Education.

Harun, H., Karen, V-P. and Eggleton, I. (2015), "Indonesian public sector accounting reforms: dialogic aspirations a step too far?", Accounting, Auditing \& Accountability Journal, Vol. 28 No. 5, pp. 706-738. 
Harun, H., Peursem, K. and Eggleton, I. (2012). "Institutionalization of accrual accounting in the Indonesian public sector", Journal of Accounting \& Organizational Change, Vol. 8 No. 3, pp. 257-285.

Hay, D. and Cordery, C. J. (2018), "The value of public sector audit: literature and history", Journal of Accounting Literature, Vol. 40 June, pp. 1-15.

Hepworth, N. (2015), "Debate: Implementing advanced public financial management reform in developing countries", Public Money \& Management, Vol. 35 No. 4, pp. 251-253.

Hepworth, N. (2017), "Is implementing the IPSASs an appropriate reform?”, Public Money \& Management, Vol. 37 No. 2, pp. 141-148.

Hooper, T., Tsamenyi, M., Uddin, S. and Wickramasinghe, D. (2009), "Management accounting in less developed countries: What is known and needs knowing", Accounting, Auditing and Accountability Journal, Vol. 22 No. 3, pp. 469-514.

Hopper, T. (2017), "Neopatrimonialism, good governance, corruption and accounting in Africa: idealism vs pragmatism", Journal of Accounting in Emerging Economies, Vol. 7 No. 2, pp. 225-248.

Hopper, T., Lassou, P. and Soobaroyen, T. (2017), "Globalisation, accounting and developing countries", Critical Perspectives on Accounting, Vol. 43 March, pp. 125-148.

Hopwood, A. G. (2000), "Understanding financial accounting practice, Accounting, Organizations and Society, Vol. 25, pp.763-766.

Hyndman, N. and Connolly, C. (2011), “Accruals accounting in the public sector: a road not always taken", Management Accounting Research, Vol. 22 No. 1, pp. 36-45.

Hyndman, N. and Liguori, M. (2018), “Achieving radical change: a comparative study of publicsector accounting in Westminister and Scotland", Accounting, Auditing \& Accountability Journal, Vol. 31 No. 2, pp. 428-455.

International Federation of Accountants (IFAC). (2011), Transition to the accrual basis of accounting: Guidance for public sector entities (3rd ed.), IFAC, New York.

IPSASB. (2017), International Public Sector Accounting Standard: Financial Reporting Under the Cash Basis of Accounting, IFAC, New York.

Jacobs, K. (2012), "Making sense of social practice: theoretical pluralism in public sector accounting research", Financial Accountability \& Management, Vol. 28 No. 1, pp. 125.

Jones, R. H. (1992), "The development of conceptual frameworks of accounting for the public sector", Financial Accountability and Management, Vol. 8 No. 4, pp. 249-264. 
Jorge, S. M., da Costa Carvalho, J. B. and Fernandes, M. J. (2007), “Governmental accounting in portugal: why accrual basis is a problem”, Journal of Public Budgeting, Accounting \& Financial Management, Vol. 19 No. 4, pp. 411-446.

Josiah, J., Burton, B., Gallhofer, S. and Haslam, J. (2010), “Accounting for privatisation in Africa? Reflections from a critical interdisciplinary perspective", Critical Perspectives on Accounting, Vol. 21 No. 5, pp. 374-389.

Kasim, E. Y. (2015), Restatement and accrual basis issue in government accounting in Indonesia, First International Conference on Economics and Banking (ICEB-15), Indonesia, pp. 201-206.

Keay, A. (2017), "Stewardship theory: is board accountability necessary?", International Journal of Law and Management, Vol. 59 No. 6, pp. 1292-1314.

Kotter, J. (2011), Change Management. Tech Faqs. Retrieved from http://www.techfaq.com/change-management.html

Kurunmaki, L, Melia, K. and Lapsley, I. (2003), “Accountingization v. legitimation: a comparative study of the use of accounting information in intensive care", Management Accounting Research, Vol. 14 No. 2, pp. 112-139.

Lapsley, I., Mussari, R. and Paulsson, G. (2009), "On the adoption of accrual accounting in the public sector: a self-evident and problematic reform”, European Accounting Review, Vol. 18 No. 4, pp. 719-23.

Lassou, P. (2017), "State of government accounting in Ghana and Benin: a "tentative" account”, Journal of Accounting in Emerging Economies, Vol. 7 No. 4, pp. 486-506.

Lassou, P. and Hopper, T. (2016), "Government accounting reform in an ex-French African colony: the political economy of neo-colonialism," Critical Perspectives on Accounting, Vol. 36 April, pp. 39-57.

Lassou, P., Hopper, T., Soobaroyen, T. and Wynne, A. (2018), "Participatory and incremental development in an African local government accounting reform", Financial Accountability \& Management, pp. 1-16.

Luder, K. G, (1992), “A contingency model of governmental accounting innovations in the political administrative environment", Research in Governmental and Non-profit Accounting, Vol. 7, pp. 99-127.

Manes-Rossi, F., Cohen, S., Caperchione, E. and Brusca, I. (2016), "Introduction: the Gordian knot of public sector accounting and the role of the international public sector accounting standards", International Review of Administrative Sciences, Vol. 82 No.4, pp. 718-723. 
Martin, C. and Jérôme, T. (2016), "Cost (in)efficiency and institutional pressures in nursing home chains", European Accounting Review, Vol. 25 No. 4, pp. 687-718.

Mbelwa, L. (2015), "Factors influencing the use of accounting information in Tanzania local government authorities (LGAs): an institutional theory approach", Research in Accounting in Emerging Economies, Vol. 15, pp. 143-177.

McLeod, R. and Harun, H. (2014), "Public sector accounting reform at local government level in Indonesia", Financial Accountability \& Management, Vol. 30 No. 2, pp. 238-258.

Mehr, A. A. (2015), "Assessment the Usefulness of Accrual Accounting on Reporting Transparency and Accountability of the Ministry of Sciences Universities”, Singapore Journal of Business Economics and Management Studies, Vol. 3No. 7, pp. 83-88.

Meyer, J. and Rowan, B. (1977), "Institutional organizations: Formal structure as myth and ceremony", American Journal of Sociology, Vol. 83 No. 2, pp. 340-363.

Mkasiwa, T. A. (2011), Accounting Changes and Budgeting Practices in the Tanzanian Central Government: A Theory of Struggling for Conformance Tausi Ally Mkasiwa Thesis for the Degree of Doctor of Philosophy, $\mathrm{PhD}$ thesis, University of Southampton.

Modell, S. (2009), "Institutional research on performance measurement and management in the public sector accounting literature: a review and assessment", Financial Accountability \& Management, Vol. 25 No. 3, pp. 277-303.

Modell, S. (2013), "Making sense of social practice: Theoretical pluralism in public sector accounting research: A comment”, Financial Accountability \& Management, Vol. 29, No. 1, pp. 99-110.

Morgan, S. L. andWaring, C. G. (2004). Guidance on Testing Data Reliability, Austin, Texas. Najeeb, A. (2014). Institutional theory and human resource management. Research, pp. 25-30.

Neu, D., Everett, J. and Rahaman, A.S. (2009), “Accounting assemblages, desire, and the body without organs: a case study of international development lending in Latin America", Accounting Auditing \& Accountability Journal, Vol. 22 No. 3, pp. 319-350.

Nyamori, R. O., Abdul-Rahaman, A. S. and Samkin, G. (2017), “Accounting, auditing and accountability research in Africa: Recent governance developments and future directions", Accounting, Auditing \& Accountability Journal, Vol. 30 No. 6, pp. 12061229.

Oliver, C. (1991), "Strategic responses to institutional processes", Academy of management review, Vol. 16 No. 1, pp. 145-179.

Oulasvirta, L. (2014), "The reluctance of a developed country to choose International Public Sector Accounting Standards of the IFAC. A critical case study", Critical Perspectives 
on Accounting, Vol. 25 No. 3, pp. 272-285.

Pina, V., Torres, L. and Yetano, A. (2009), “Accrual Accounting in EU Local Governments: One Method, Several Approaches", European Accounting Review, Vol. 18 No. 4, pp.765-807.

Pollanen, R. and Loiselle-Lapointe, K. (2012), “Accounting reform in the government of Canada: Exploratory evidence on accrual accounting adoption and impact", Financial Accountability and Management, Vol. 28 No. 4, pp. 359-377.

Potter, B. (2002), "Financial accounting reforms in the Australian public sector", Accounting, Auditing \& Accountability Journal, Vol. 15 No. 1, pp. 69-93.

Rollins, T. P. and Bremser, W. G. (1997), “The sec's enforcement actions against auditors: an auditor reputation and institutional theory perspective", Critical Perspectives on Accounting, Vol.8 No. 3, pp. 191-206.

Salah, U., R., Adhikari, P., Hoque, M. and Akter, M. (2018), "Institutionalisation of the cash basis international public sector accounting standard in the central government of Bangladesh: an example of delay and resistance", Journal of Accounting in Emerging Economies (forthcoming)

Samkin, G. and Schneider, A. (2010), “Accountability, narrative reporting and legitimation”, Accounting, Auditing \& Accountability Journal, Vol. 23 No. 2, pp. 256-289.

Saunders, M. (2009), Research methods for business students (fifth edit), Pitman Publishing, Essex.

Scapens, R. (2006), 'Understanding management accounting practices: a personal journey 'The British Accounting Review, Vol. 38 No. 1, pp.1-30.

Schipper, K. and Vincent, L. (2003), "Earnings quality”, Accounting Horizons, Vol. 17, pp. 97-110.

Scott, W. (1991), “Unpacking Institutional Arguments”, in Powell, W.W. and DiMaggio, P. (Eds.), The New Institutionalism in Organizational Analysis, University of Chicago Press, Chicago, pp. 164-182.

Shenton, A. (2004), "Strategies for ensuring trustworthiness in qualitative research projects", Education for Information, Vol. 22, pp. 63-75.

Soobaroyen, T., Tsamenyi, M. and Sapra, H. (2017), “Accounting and governance in Africa contributions and opportunities for further research", Journal of Accounting in Emerging Economies, Vol. 7 No. 4, pp. 422-427.

Staubus, G. (1960), The Decision Usefulness Theory of Accounting, Garland Publishing Inc. New York. 
Steccolini, I. (2019), “Accounting and the post-new public management: reconsidering publicness in accounting research", Accounting, Auditing \& Accountability Journal, Vol. 32 No. 1, pp. 255-279.

Sutton, D. (2009), The Foundations for a General Theory of General Purpose Financial Reporting for Businesses, Master Thesis, Victoria University of Wellington.

Tabachnick, B. and Fidel, L. (1996), Using Multivariate Statistics, Harper Collins College Publisher.

Taipaleenmäki, J. and Ikäheimo, S. (2013), “On the convergence of management accounting and financial accounting - the role of information technology in accounting change", International Journal of Accounting Information Systems, Vol. 14 No. 4, pp. 321-348.

Taylor-Powell, E. and Hermann, C. (2000), Collecting Evaluation Data: Surveys, University of Wisconsin, USA.

Timoshenko, K. and Adhikari, P. (2009), "Exploring Russian central government accounting in its context", Journal of Accounting \& Organizational Change, Vol. 5 No. 4, pp. 490513.

Uddin, S. and Hopper, T. (2001), “A Bangladeshi soap opera: privatisation, accounting, and regimes of control in a less developed country", Accounting, Organizations and Society, Vol. 26 Nos 7/8, pp. 643-72.

Uddin, S. and Hopper, T. (2003), “Accounting for privatisation in Bangladesh: testing World Bank claim”, Critical Perspectives on Accounting, Vol. 14 No. 7, pp. 739-74.

Uddin, S. and Tsamenyi, M. (2005), "Public sector reforms and the public interest: a case study of accounting control changes and performance monitoring in a Ghanaian state-owned enterprise", Accounting, Auditing \& Accountability Journal, Vol. 18 No. 5, pp. 648-74.

United Republic of Tanzania (URT). (2008), Report of Controller and Auditor-General on Local Government Authority accounts for the period ended 30th June, Government Printer, Dar es Salaam.

United Republic of Tanzania (URT). (2010), United Republic of Tanzania 2009 Public Financial Management Performance Report on Mainland Tanzania :Public Financial Management Working Group Tanzania,(November), Dar es Salaam.

United Republic of Tanzania (URT). (2012), The Annual General Report of The Controller and Auditor General On the Financial Statements of the Central Government (MDAs) For the Year Ended 30th June. Government Printer, Dar es Salaam

United Republic of Tanzania (URT). (2013a), Public Financial Management Reform Programme ( PFMRP) Joint Supervision Mission AIDE MEMOIRE ( REPORT) 
FINAL, Dar es Salaam.

United Republic of Tanzania (URT). (2013b), The Annual General Report of The Controller and Auditor General On the Financial Statements of the Central Government (MDAs) For the Year Ended 30TH JUNE, 2013, Dar es Salaam.

United Republic of Tanzania (URT). (2014). The Annual General Report of The Controller and Auditor General on The Financial Statements For the year Ended 30TH JUNE, 2014 (Vol. 255), Dar es Salaam.

United Republic of Tanzania (URT). (2015). The Annual General Report of the Controller and Auditor General Report on the Financial Statements For the Year Ended 30TH JUNE, 2015 Central Government (Vol. 255), Dar es Salaam.

Vamosi, T. (2005), "Management accounting and accountability in a new reality of everyday life", The British Accounting Review, Vol. 37 No. 4, pp. 443-470.

Van Helden, J. and Uddin, S. (2016), "Public sector management accounting in emerging economies: a literature review", Critical Perspectives on Accounting, Vol. 41 December, pp. $34-62$.

Van Wyk, H.A. (2007), "Is the transformation of public sector financial reporting in South Africa's provincial governments on track?", Meditari Accountancy Research, Vol. 15 No. 2, pp. 65-75.

Wall, A. and Connolly, C. (2016), "Implementing IFRSs in the UK developed administrations", Accounting, Auditing \& Accountability Journal, Vol. 29 No. 2, pp. 198-225.

Williams, P. (1987), "The legitimate concern with fairness", Accounting Organizations and Society, Vol. 12 No. 2, pp 169-189.

World Bank. (2008), Public Sector Reform, 'What Works and Why; An IEG Evaluation of World Bank Support, World Bank InfoShop, Washington.

Wynne, A. (2012), "Editorial”, International Journal on Governmental Financial Management, Vol. XII No. 1, 2012.

Wynne, A. (2013), International Public Sector Accounting Standards: Compilation Guide for Developing Countries, International Consortium on Governmental Financial Management, available at: http://www.scribd.com/doc/134603499/ICGFMCompilation-Guide-to-Financial-Reporting-by-Governments. Accessed 29 August 2014.

Yin, R. (2009), Case Study Research: Design and Methods, Thousand Oaks, Sage, CA. 